GORAN STOJIĆ

Centre for New Technologies Viminacium

Belgrade, Serbia

E-mail: stojicgoran@gmail.com

MILICA MARJANOVIĆ

Institute of Archaeology

Belgrade, Serbia

E-mail:milicamitic87@yahoo.com
Received: November $30^{\text {th }} 2020$

Accepted: December $10^{\text {th }} 2020$

Original research article 904:725(497.11)"03"

902.2(497.11)"2018"

COBISS.SR-ID 29184777

https://doi.org/10.18485/arhe_apn.2020.16.3

\title{
LATE ROMAN BUILDING AT THE ČAIR-CASTRUM SITE: CONTRIBUTION TO THE STUDY OF THE PROFANE ARCHITECTURE OF VIMINACIUM
}

\begin{abstract}
A late Roman horizon comprised of multiple units was investigated in the area of a defensive ditch during the excavations of the western gate zone of Viminacium's legionary camp in 2018. The subject of this paper, marked as building 7 in the internal documentation, was among them. Building 7 was located to the southwest of the gate, and it is oriented parallel to the western rampart of the camp. It was built after the filling of the defensive ditch, over the layers of its filling, using different techniques and materials. According (mostly) to coins, the building is dated to the fourth century. Small finds in the building point to everyday and economic activities, except for several finds of weaponry. In a broader context and in relation to other structures discovered in the extramuros zone of the western rampart, building 7 can be interpreted as an economic structure that was part of a larger craftsmanship complex.
\end{abstract}

KEYWORDS: LATE ANTIQUITY, FOURTH CENTURY, MOESIA PRIMA, VIMINACIUM, LATE ROMAN ARCHITECTURE, SMALL FINDS.

\section{INTRODUCTION}

Roman Viminacium was founded in the first century A.D., at a strategically important location near the former confluence of the Mlava and Danube rivers. At that time, the Roman legions VII Claudia and IV Flavia built a military fortification there, and soon a civilian settlement was founded in its immediate vicinity. Over time, the importance and role that Viminacium had in the province of Moesia Superior grew, so that this fortification became a permanent camp of VII Claudia legion. The settlement received the status of municipium during the reign of Emperor Hadrian, and from the middle of the second cen- tury it was recorded as the capital of the Moesia Superior province. The city also flourished in the third century, beginning with the reign of Septimius Severus, while during the reign of Gordian III it gained the status of colony. Viminacium also existed throughout the late Roman period, when it was recorded as the capital of the province of Moesia Prima and the episcopal see. Viminacium disappeared under the onslaught of barbarian tribes in the middle of the fifth century (Korać, Golubović and Mrđić, 2018: 42, 44-45; Mirković 1968: 56, 68-69; Mirković 1986: 21-27). Archaeological data indicate that the city and the camp itself were not rebuilt after that, but life continued in its immediate vicinity in the early Middle Ages. 


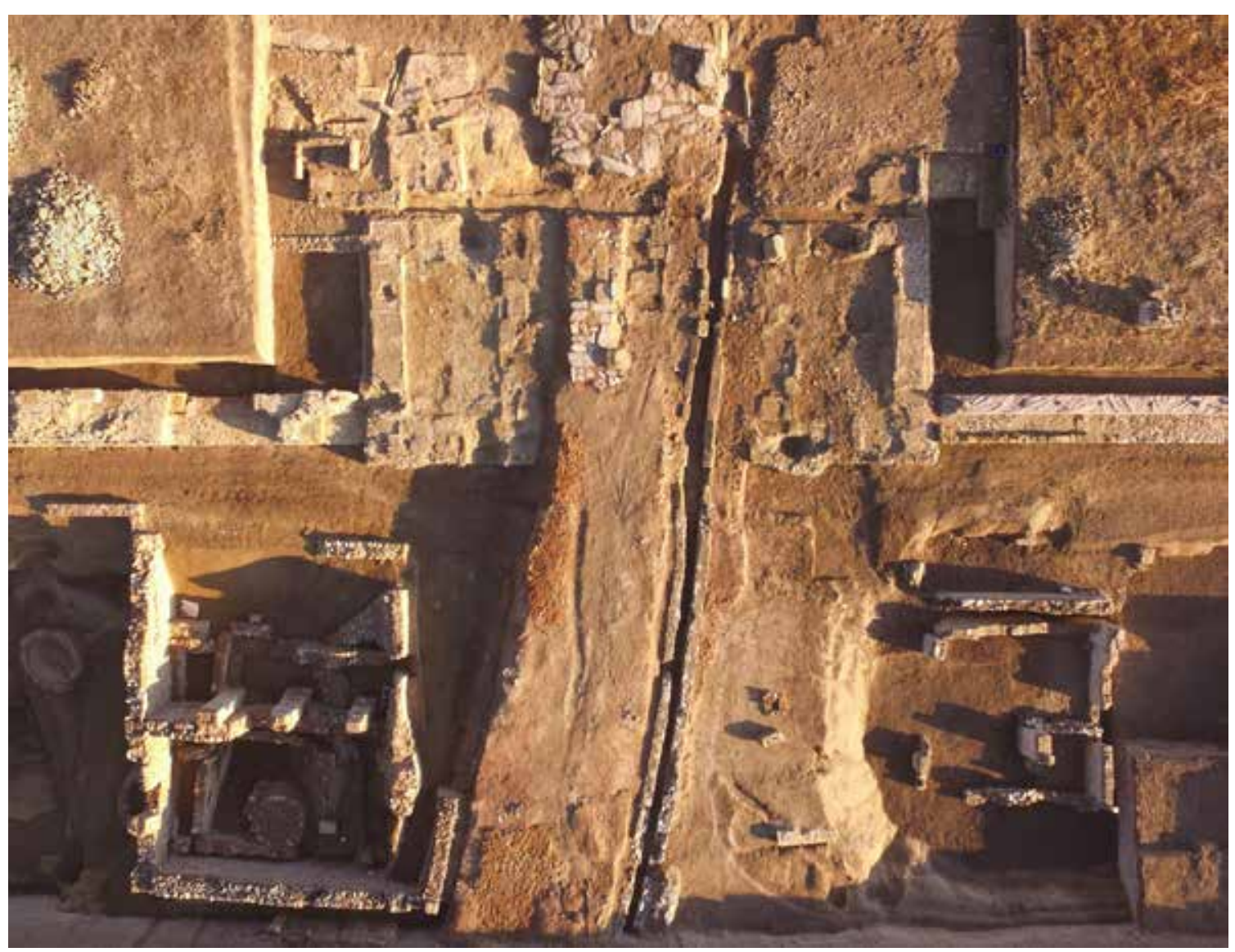

Fig. 1 Aerial view of the excavated area in front of the western gate (building 7 is in the lower right corner of the photo)

Archaeological investigations of Viminacium began at the end of the $19^{\text {th }}$ century, and they were conducted on multiple occasions during the 20th century. A new series of multidisciplinary investigations began on various locations at the beginning of the 21st century, in 2002 to be more precise. Apart from excavations, geophysical prospection was carried out on some of its parts (Korać, Golubović and Mrđić 2018: 54-55). Protective excavations, followed by systematic excavations, have continuously been carried out in the area of the VII Claudius's legion's camp since 2016. These latest excavations have mostly focused on the northwestern section of the fortification and its immediate surroundings; they have also been carried out in the area of principia in the middle part of the fortification since 2020. Two main phases of the construction of the camp were identified during excavations of the ramparts and gates, of which the older phase dates back to the time of the Flavian dynasty, and the younger to the second century, most likely to the time of Emperor Trajan. Several different units were explored in this area - parts of the northern and western ramparts with accompanying towers, parts of the defensive ditch that surrounded it, the western and northern gates of the camp, part of the via principalis, and the street that extended from it. A sewage system, part of the thermae, a fountain, and several buildings were discovered in the interior of the camp, while in the extramuros zone, a smaller necropolis, several economic buildings, and buildings of unknown use were explored, mostly over the filled defensive ditch. ${ }^{1}$

1 Preliminary results of the excavations have been published in several issues of „Arheologija u Srbiji“ - Nikolić, Stojić, Marjanović 2018, Nikolić et al. 2019, Nikolić, Stojić, Marjanović 2020. 


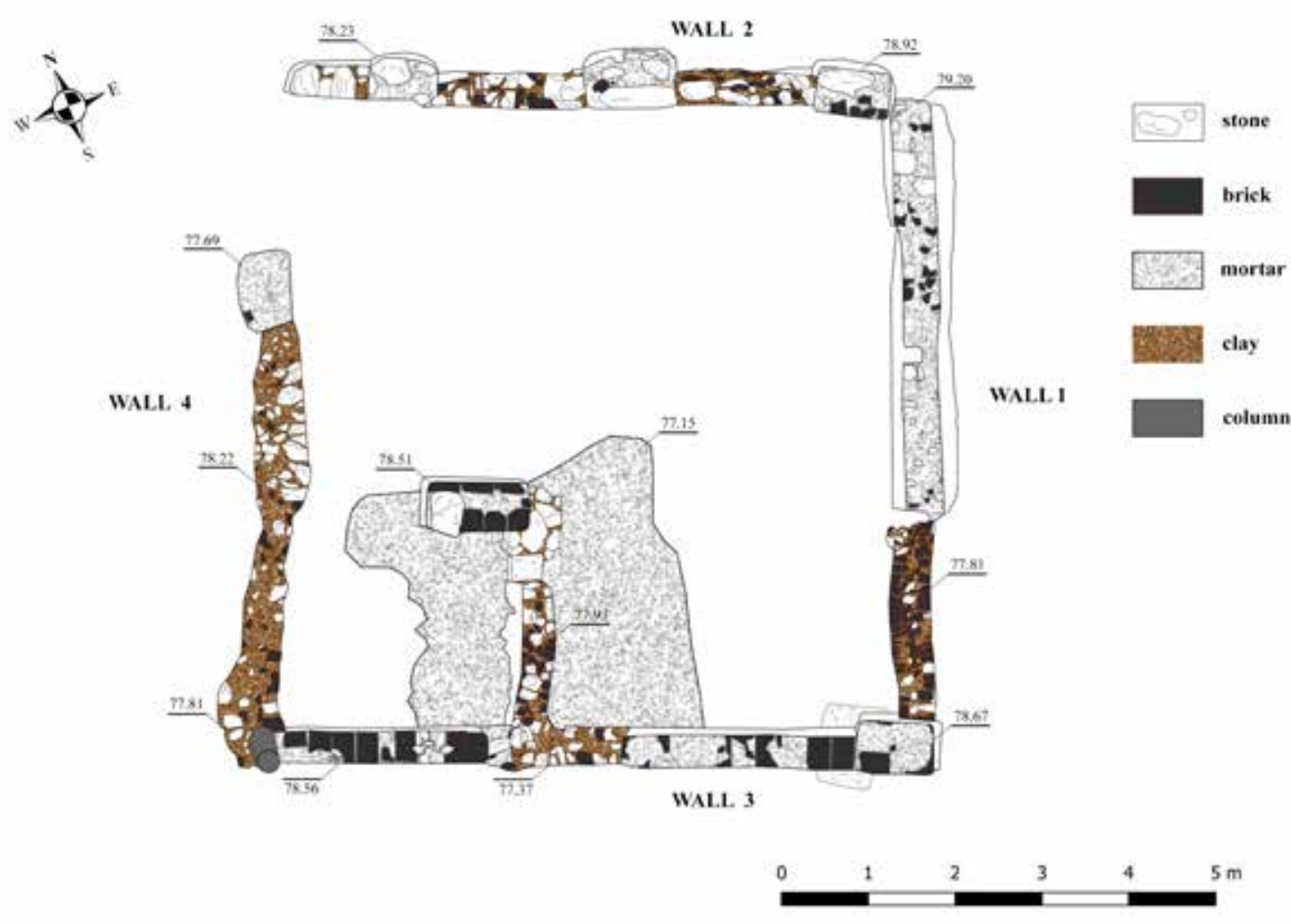

Plan 1 Layout plan of the building 7 (by M.Milovanović)

Excavations were also carried out in the area in front of the western gate of the fortification (Fig. 1) where, in addition to a smaller necropolis, several buildings from the late Roman horizon were discovered during the campaign of 2018 (Nikolić, Stojić i Marjanović 2020). These units were erected mostly in the area of the defensive ditch after it was filled up, and they are located to the north and south of the pathway that led from the western gate of the camp to the city. Seven buildings, built mostly using the drywall technique, were investigated, as well as five kilns. The discovered units indicate the predominantly economic character of this area in late antiquity. The subject of this paper is one of the late Roman buildings investigated in the area of the western gate of the camp, marked in the internal documentation as Building $7 .^{2}$

2 Since the building stretched over two different trenches, it was investigated on two occasions. Excavations of the eastern part of the building were led by Saša Redžić and Mladen Jovičić, while the western part of the building was researched by Snežana Nikolić, Goran Stojić and Milica

\section{BUILDING 7}

Building 7 was discovered to the southwest of the western gate of the military camp, at a distance of about $8 \mathrm{~m}$ from the western rampart (extramuros) (Fig. 2). The building is located above the defensive ditch and is parallel to the ramparts of the camp.

Building 7 has an irregular rectangular, almost square base, whose external dimensions are 8.10 / $7.70 \times 7.75$ / $6.90 \mathrm{~m}$ (Plan 1). The walls of the building are not structurally connected, but the sides lean on each other, and their highest preserved height is $1.27 \mathrm{~m}$. Since the building was erected in the area above the defensive ditch, the foundations were not laid in sterile soil, but in layers of its filling. Various materials were used in the construction of the building - fragments of bricks, tegulae and imbrices, schist stone and limestone

Marjanović. It should be noted that a part of wall 2 collapsed due to unfavorable atmospheric conditions during the intermission between the two excavations. 


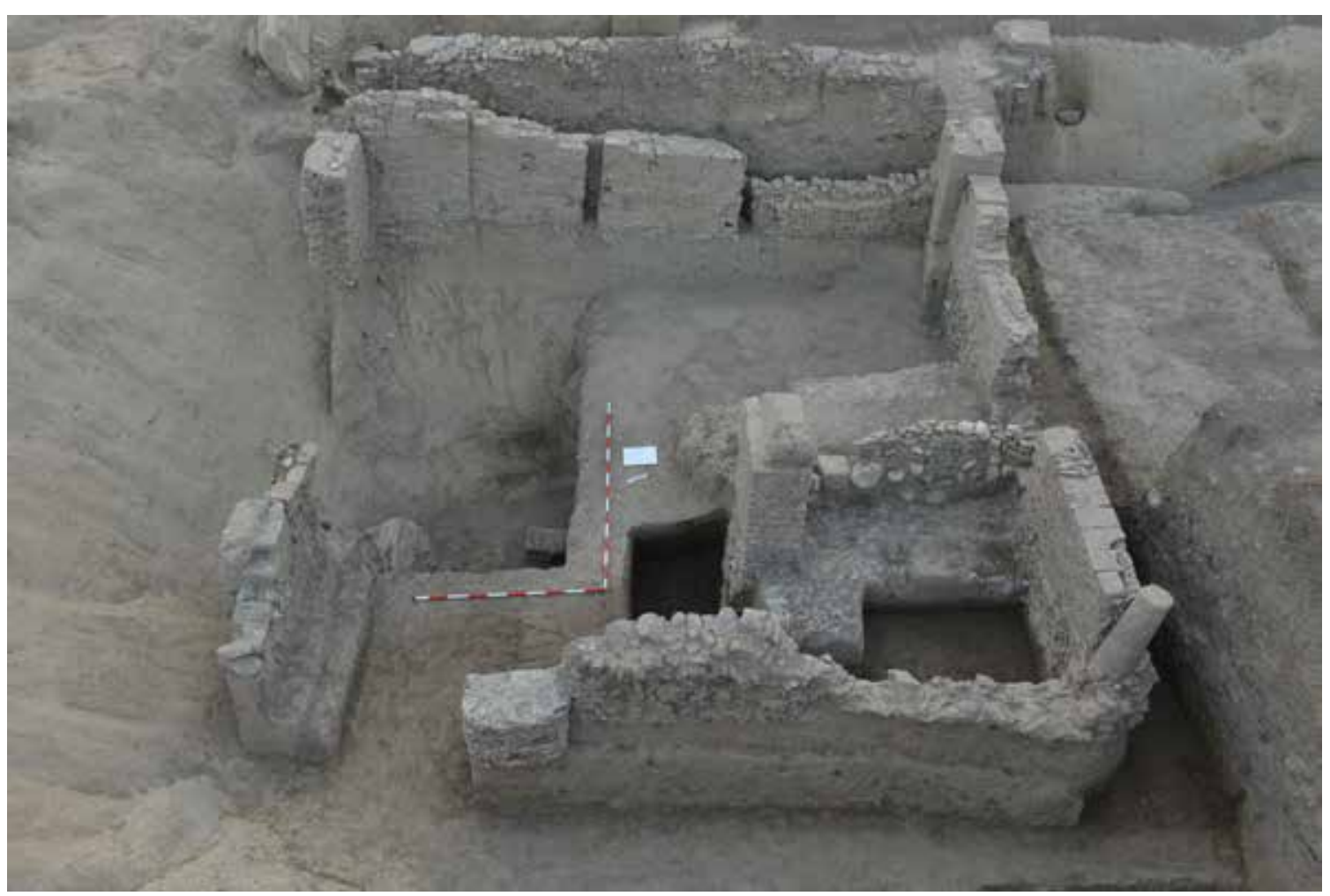

Fig. 2 Bulding 7, view from the west

blocks, sporadically "crvenka", ${ }^{3}$ while lime mortar and clay were used as binding material. A larger area with mortar and small rubble was discovered inside the building. It could have been a floor or the base on which it was set. The walls of the building were built using different techniques and materials, so in order to describe the method of construction, it is necessary to describe each wall of the building in detail.

Wall 1 is oriented north-south (Fig. 3), its length is $7.70 \mathrm{~m}$, and its width varies from $0.40 \mathrm{~m}$ to $0.50 \mathrm{~m}$. It was built of brick and broken schist, while lime mortar was used as binding material. The construction of the wall itself can be divided into three parts, i.e. three unequal segments.

The first, southern segment of the wall is represented by pilaster 5 . The pilaster has a rectangular base, and dimensions of $0.85 \mathrm{~m} \times 0.60 \mathrm{~m}$. It was

3 "Crvenka“ (red clay) is a raw material, exploited locally in Stari Kostolac. It is a kind of naturally burnt soil, sometimes described as a "natural brick" (Nikolić 2013: 27-28). built of bricks with lime mortar, and its preserved height is $1.27 \mathrm{~m}$ (without the foundation zone).

The second segment of the wall was built using the drywall technique, from horizontally laid and sloping bricks, arranged next to each other, while clay was used as binding material. On the south side, the segment rests on the northern edge of pilaster 5, while on the north side it borders a groove for a wooden beam 1. Its length is $2.25 \mathrm{~m}$, width about $0.45 \mathrm{~m}$, while the preserved height does not exceed $0.60 \mathrm{~m}$.

The third segment of the wall was built of pieces of schist stone, bricks and sporadically "crvenka", tied with mortar. It extends from the groove for the wooden beam 1 towards the northern end of the wall, i.e. pilaster 9 . The length of the segment is $4.85 \mathrm{~m}$, width about $0.42 \mathrm{~m}(0.49 \mathrm{~m}$ at the pilaster), and the preserved height is $1.20 / 1.35$ $\mathrm{m}$. In this segment, there are two "grooves" for wooden beams of rectangular cross-section, 0.20 $\mathrm{m}$ and $0.23 \mathrm{~m}$ wide, and the distance between them is $1.70 \mathrm{~m}$. The so-called pilaster 9 is at the 


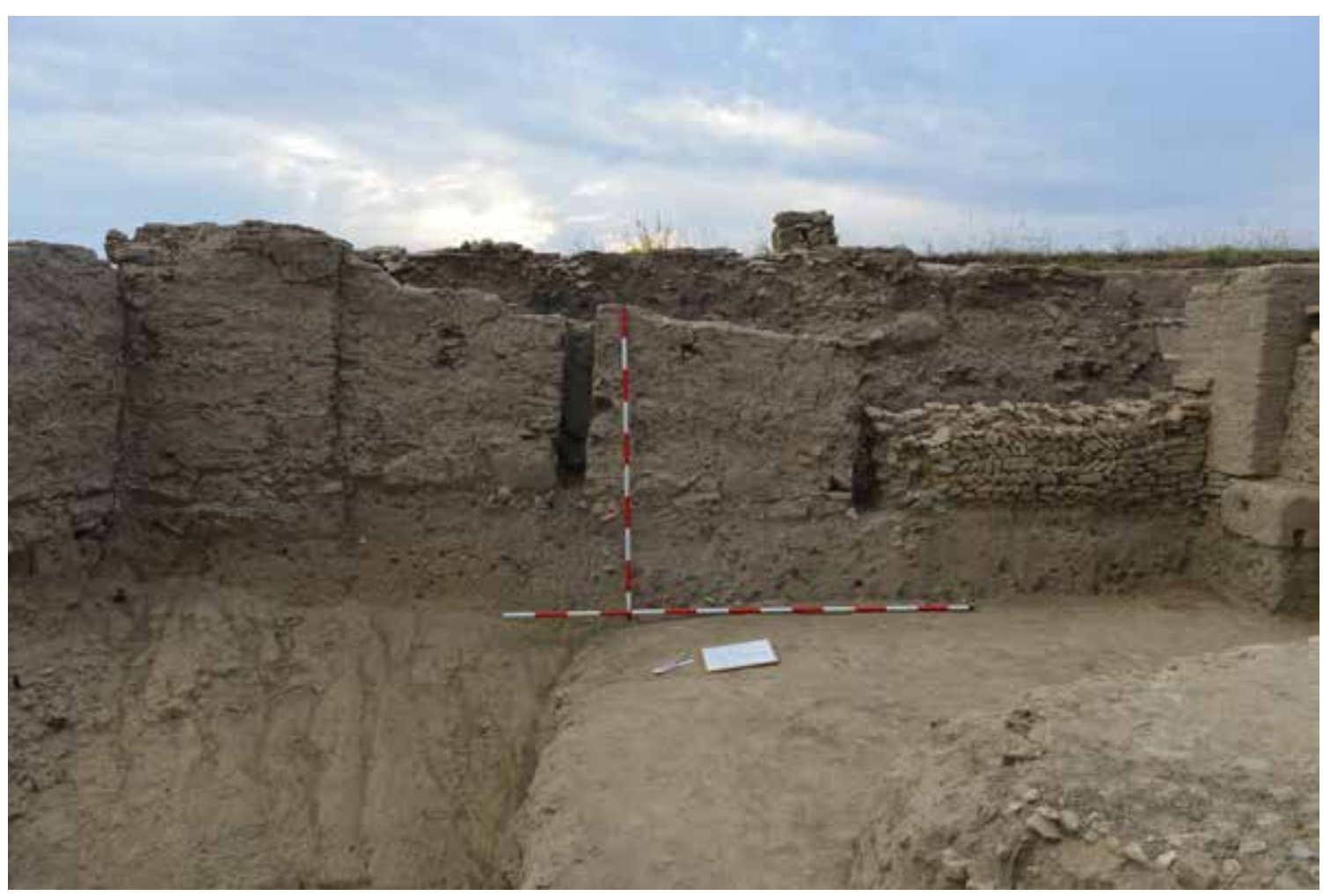

Fig. 3 Wall 1 (eastern wall), view from the west

northern end of this segment. It is structurally connected to the rest of the segment, but it stands out from the rest of the wall in terms of its shape and massive size. The dimensions of the pilaster are $1.45 \times 0.49 \mathrm{~m}$, it is oriented north-south, and it was built of mortar-bound bricks. On the outer, east side, the third segment is covered with a strong layer of plaster.

The foundation zone of wall 1 is of a somewhat better construction quality below pilaster 9 and it consists of fragmented bricks, tegulae, and schist bound with clay, about $0.40 \mathrm{~m}$ high. Below the second segment, the foundation zone could only be represented by the unplastered lower part of the wall whose height is about $0.10-0.15 \mathrm{~m}$.

Wall 2 is oriented east-west, from pilaster 9 in the east to the edge of wall 4 in the west (Fig. 4). Its length is $6.90 \mathrm{~m}$, and the preserved height does not exceed $1.15 \mathrm{~m}$ (without the foundation zone). It was built of crushed schist, limestone, and brick fragments, while lime mortar and yellow clay were used as binding material. The construction of the wall itself consists of three pilasters and the rest of the wall is made using the drywall technique. Pilasters 1,2 and 3 are rectangular at their bases, measuring 1.00-0.75 $\mathrm{m} \times 0.50-0.40 \mathrm{~m}$, built of schist and brick fragments, while lime mortar was used as binding material. The space between the pilasters and the western end of the wall itself, were built of broken schist, fragments of bricks and tegulae, which could have been arranged horizontally in irregular rows or slantwise. Yellow clay was used as binding material in spaces between pilasters.

The foundation zone is clearly visible only beneath the pilasters, while under the walls it was found only in the part of the wall near pilaster 9 . The upper part of the wall is separated from the foundation by horizontally arranged fragments of tegulae and schist. The foundation zone below the eastern part of the wall consists of pieces of schist, fragments of bricks and tegulae bound with clay, and its height is about $0.40 \mathrm{~m}$.

Wall 3 is oriented east-west, from the end of wall 1 in the east to the edge of wall 4 in the west 

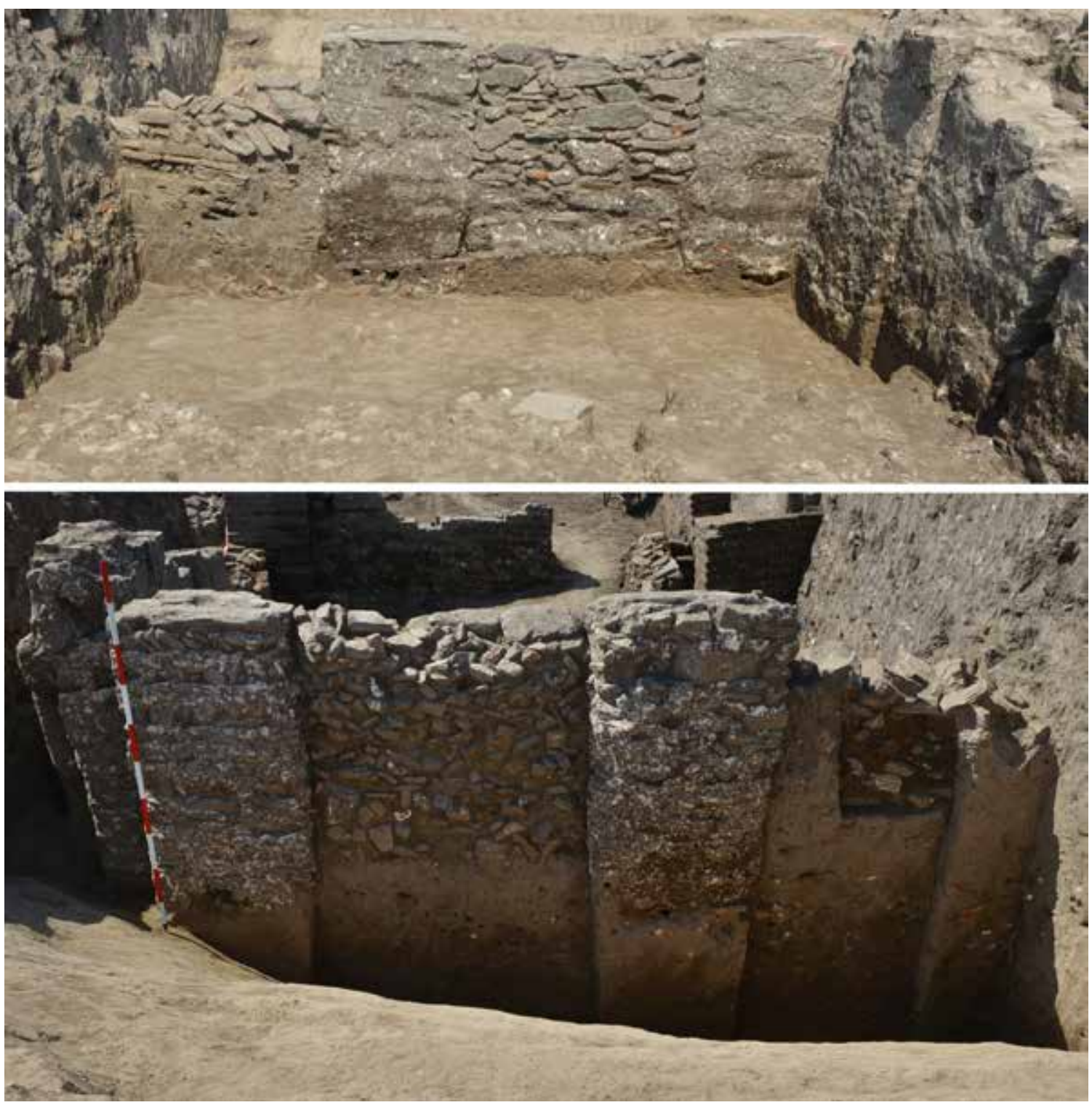

Fig. 4 Wall 2 (northern wall); upper- view from the south, lower-view from the north

(Fig. 5). Its length is $7.75 \mathrm{~m}$ and width is about $0.38 \mathrm{~m}$. It was built of bricks, mostly arranged in regular rows, while slate is also used sporadically. Lime mortar was used as binding material. The wall consists of pilaster 5 described above at the south-east corner, and the rest of the structure, which leans on it and extends further west. At the western end of the wall there is a fragmented stone column, whose diameter is about 0.30 $\mathrm{m}$, and which is preserved at a height of $1.10 \mathrm{~m}$. This column was in secondary use and was used as building material, instead of a pilaster in the corner of the room. The entrance to building 7 is located in the central part of this wall, at a distance of about $2.70 \mathrm{~m}$ from pilaster 5 . The sides of the entrance were made at right angles, and the threshold is $1.53 \mathrm{~m}$ long and about $0.38 \mathrm{~m}$ wide.

Special attention was paid to the construction of the foundation zone of wall 3, whose height is about $0.50-0.60 \mathrm{~m}$. Three levels of stacked stone and bricks can be distinguished on the western side of the foundation zone, where the lowest level is made of smaller fragments of bricks, tegulae and schist stone bound with yellow clay (individ- 


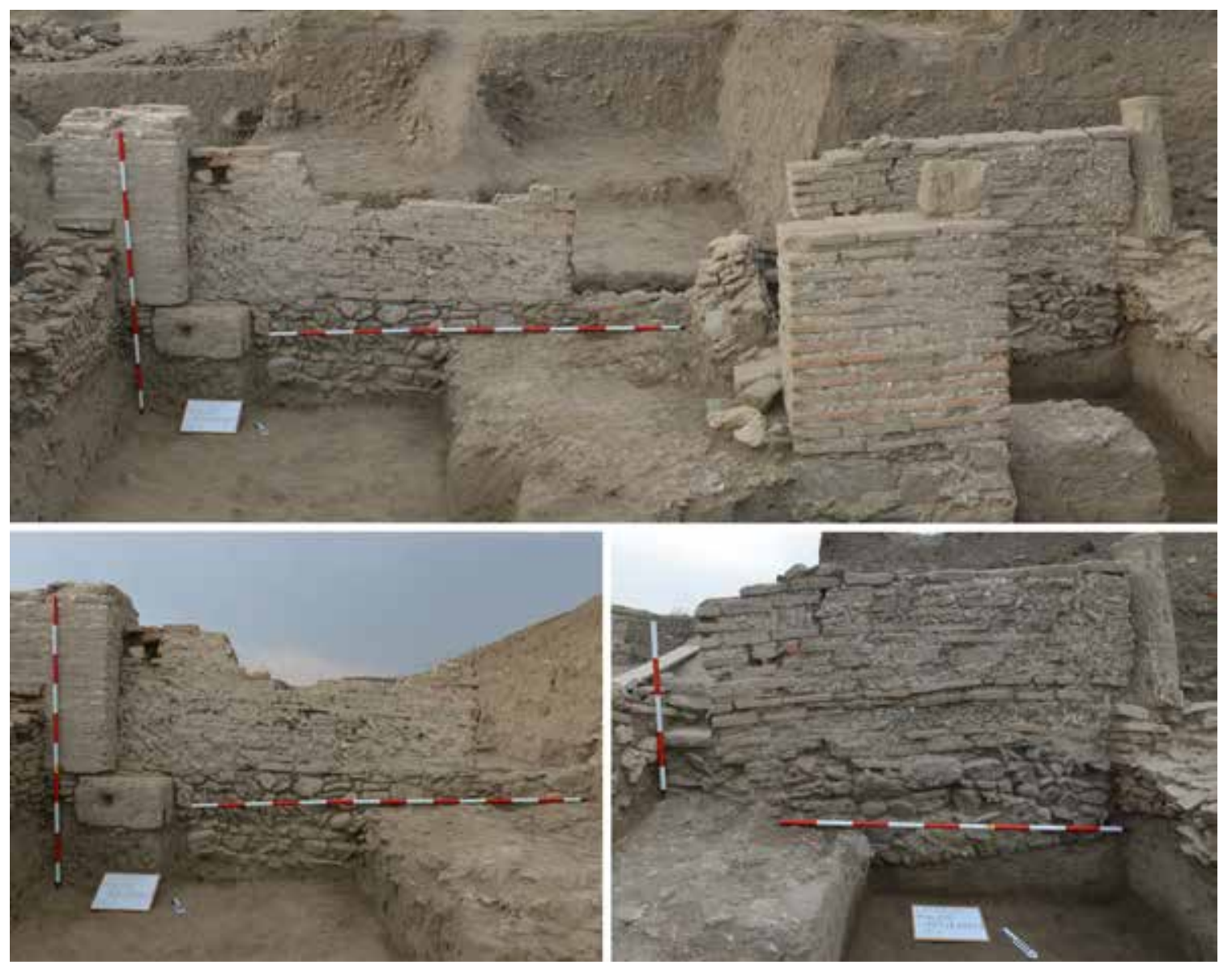

Fig. 5 Wall 3 (southern wall), view from the north

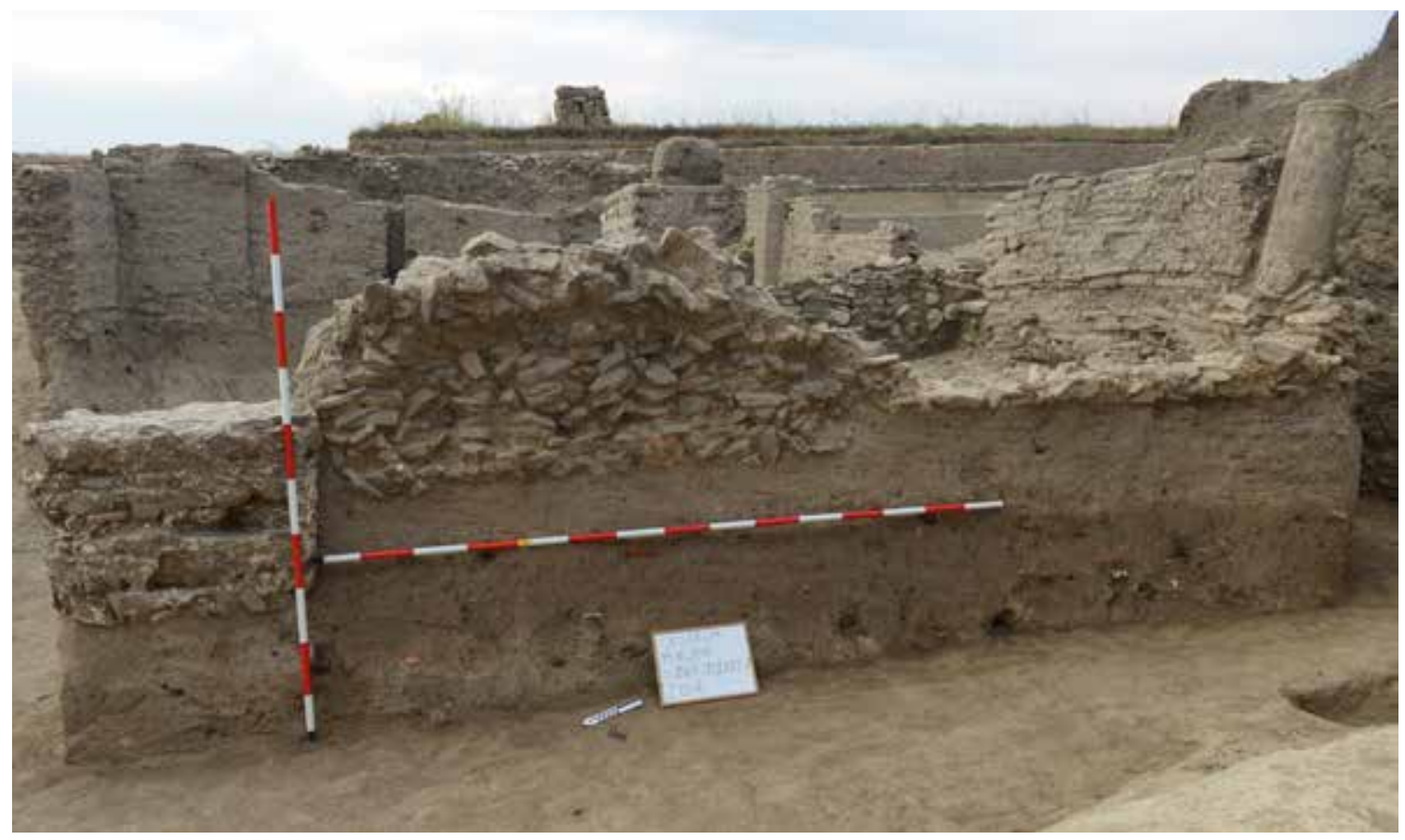

Fig. 6 Wall 4 (western wall), view from the west 
ual pieces of bricks and tegulae are in a slanting position), the second or central part of slightly larger pieces of schist and limestone bound with yellow clay, and the third or highest part was built of larger pieces of limestone (fragments of limestone blocks) bound with lime mortar. The eastern side of the foundation zone was built of pieces of schist, fragments of tegulae and bricks of approximately the same size, and the different levels of stacking are not clearly visible. In the eastern part of the foundation zone of wall 3 and pilaster 5, a larger block of limestone, measuring $0.61 \times 0.86$ $\mathrm{x} 0.32 \mathrm{~m}$, was inserted, as well as pieces of bricks and slate bound with clay.

Wall 4 is oriented north-south, from the end of wall 2 in the north to the end of wall 3 in the south (Fig. 6). Its length is $8.10 \mathrm{~m}$, the width varies from 0.40 to $0.60 \mathrm{~m}$, and the highest preserved height is $1.15 \mathrm{~m}$. Like wall 1 , wall 4 can also be divided into segments, i.e. four segments, built of broken slate, fragments of bricks, tegulae and imbrices. The first segment is located at the southern end of the wall and was founded somewhat shallower, it has a light yellow clay as binding material, and its northern side rests on the second segment. In its southern part, there are 7 rows of bricks, above which a part of the already mentioned stone pillar was placed horizontally, with a preserved height of $1.10 \mathrm{~m}$. The second segment is the best-preserved part of the wall, which extends from segment 1 to pilaster 8 , over the length of $2.60 \mathrm{~m}$. It was founded a little deeper, and dark yellow clay was used as a binding material. Pilaster 8 certainly represents the best built part of the wall. It has a rectangular base, it is oriented north-south, and is located at a distance of $2.30 \mathrm{~m}$ from the northwest corner of the building. The dimensions of the pilaster are $0.85 \times 0.60 \mathrm{~m}$, the preserved height is about 0.80 $\mathrm{m}$ (with the foundation zone). It was built of broken schist, fragments of bricks and tegulae, while lime mortar was used as binding material. The last, fourth segment of the wall, about $2.30 \mathrm{~m}$ long, has not been preserved. This wall was certainly built using a poorer technique and poorer material,

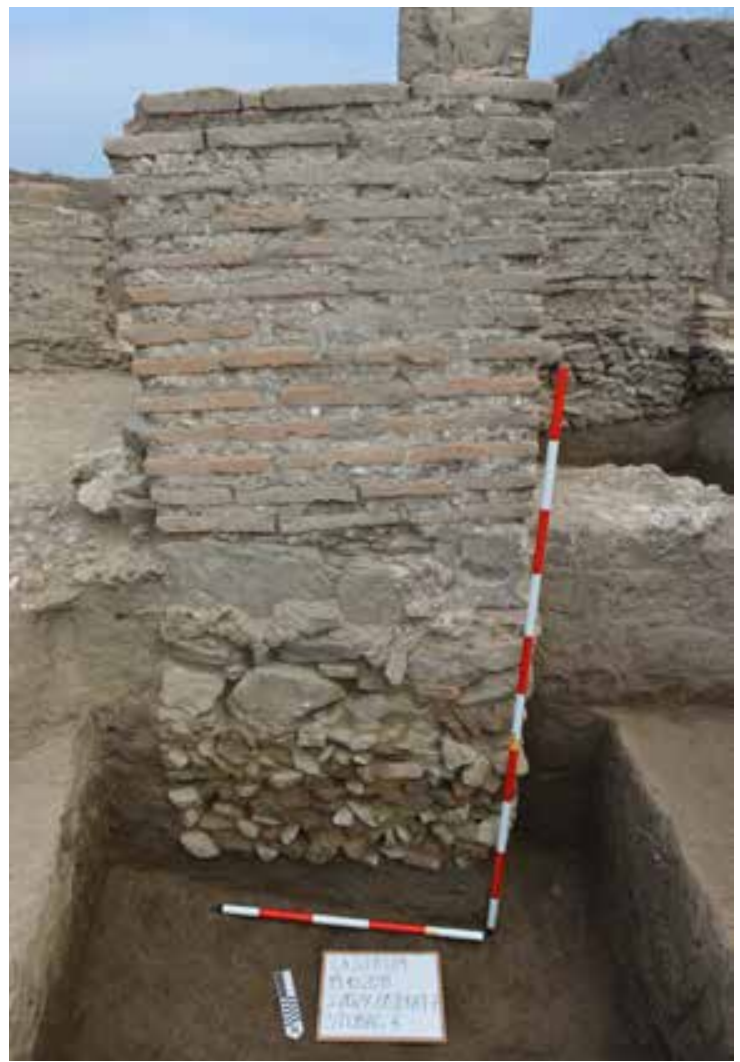

Fig. 7 Pilaster 4, view from the north

which caused it to lean to the east.

Wall 4 is mostly poorly founded, and its foundation zone is only $0.20-0.30 \mathrm{~m}$, except for the foundation of pilaster 8 . The foundation was built of brick fragments and pieces of schist bound with yellow clay. The foundation zone of pilaster 8 , as well as other pilasters, was built of broken slate and fragments of bricks and tegulae, bound with mortar.

In the central part of the western half of the building is its best built part, pilaster 4 (Fig. 7). The pilaster has a rectangular base and it is oriented east-west. Its dimensions are $1.18 \mathrm{~m} \times 0.57 \mathrm{~m}$, the preserved height is $1.22 \mathrm{~m}$ (without the foundation zone) and it was built of 13 rows of bricks bound with mortar. There is a limestone block on the column itself, which could indicate the way the upper part of the column was built. The height of the pilaster with the limestone block on it is about $1.50 \mathrm{~m}$. The bricks used in the construction of the column are $0.39 \times 0.27 \times 0.055 \mathrm{~m}$ in size. 


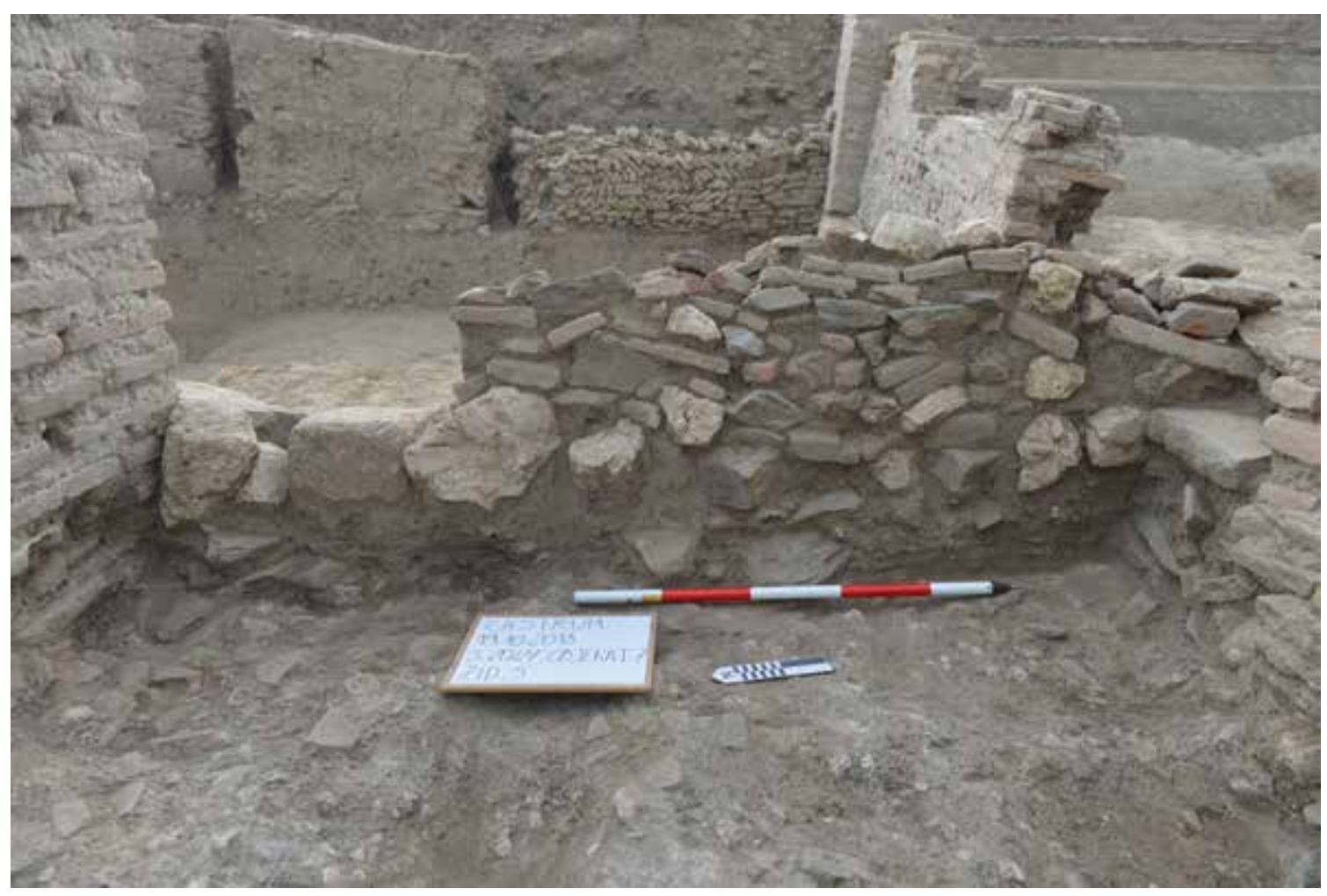

Fig. 8 Wall 5, view from the west

The foundation zone of pilaster 4 , with a height of $1.26 \mathrm{~m}$, is the most deeply founded element of the building. The foundation consists of three levels: the first or the highest part, which consists of smaller blocks of limestone, the second or central part, which consists of pieces of schist, and the third or lowest part, which was made of brick and schist fragments bound with yellow clay. Based on the position, massive size, and depth of the foundation, it can be concluded that the purpose of pilaster 4 was to support the roof or the floor.

The only inner wall, wall 5, is oriented northsouth, from the entrance to the building on wall 3 to the south, to pilaster 4 to the north (Fig. 8). Its dimensions are $2.95 \mathrm{mx} 0.35 \mathrm{~m}$, and the preserved height is $0.65 \mathrm{~m}$. It was built of brick and schist using the drywall technique, and differs in its construction technique from wall 3 and pilaster 4 on which it rests. It most likely belongs to the younger phase, or perhaps to some partitioning done later. A smaller space in the southwestern part of the building was created with this added wall.

The floor of the building was discovered in the central part of the building and in its southern half. The floor is irregular in shape, with maximum dimensions of $4.80 \times 3.90 \mathrm{~m}$, and consists of a sporadically flattened layer of lime mortar, $5-10 \mathrm{~cm}$ thick. The substructure of the floor is most likely a surface made of pieces of limestone, schist, brick and lime mortar, which was discovered at a slightly lower level and on a larger surface. The height at which the floor is located corresponds to the level of the threshold and the upper level of the foundation zone of the walls, so this level is defined as the level of use of the building.

The building itself was mostly built using high-quality materials, such as whole and fragmented bricks, tegulae and imbrices, limestone blocks and broken schist bound with mortar. In addition, spolia were used, such as a stone column 

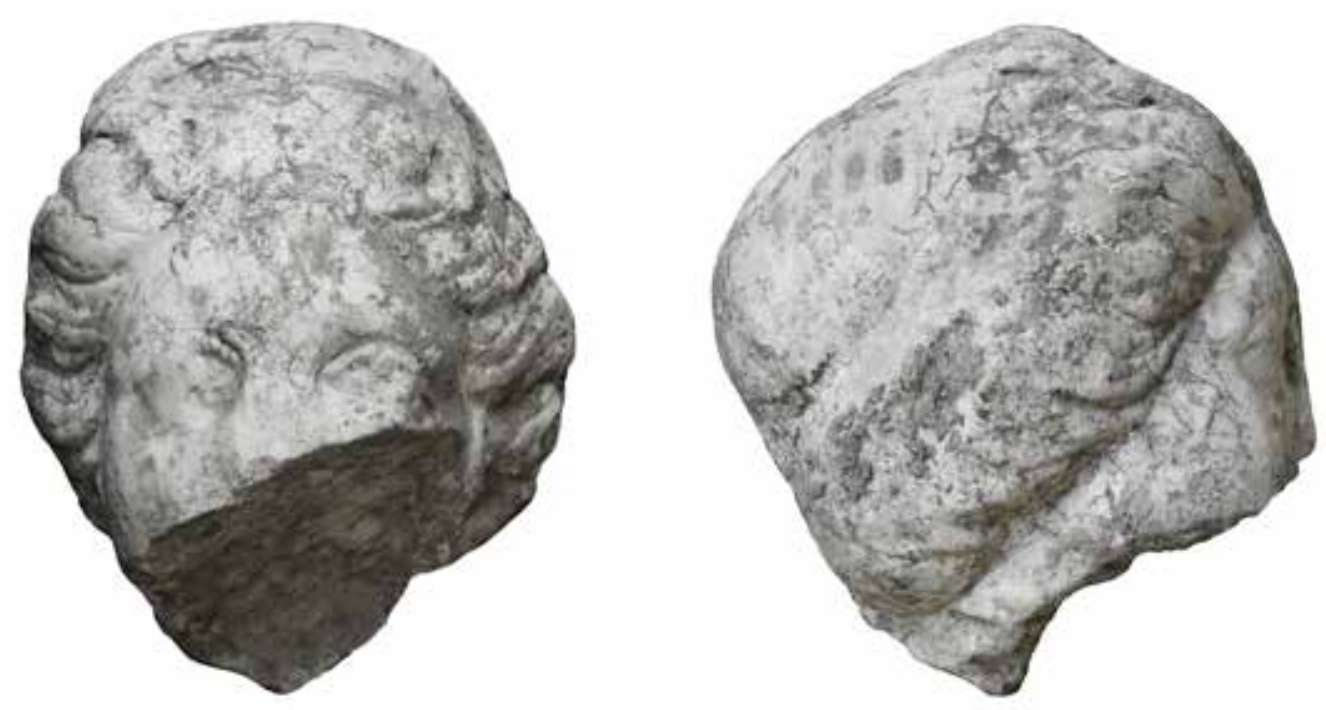

Fig. 9 Head of a female statue

in the southwest corner of the building, parts of the head of a female statue (Fig. 9) and a limestone block with two grooves in the southeast corner. It can be concluded that the masons used all available resources. Two different construction techniques were used in the construction of walls 2 and 4 - binding material in some parts is clay, while other parts were built using mortar. It was probably unnecessary to erect entire walls, half-buried (or buried?) with the use of mortar for economic reasons or lack of materials. However, certain walls had to be of stronger construction in order to increase the integrity of the entire building, or to support the wooden beams of the roof construction (or the upper floor?). It should be noted that no traces of any wooden construction were detected on walls 2, 3 and 4 . The only elements that indicate the existence of a wooden structure are the grooves for the beams on wall 1 . This leads to the conclusion that the beams were placed vertically and carried the roof structure.

The building technique of wall 3 , as well as that of pilasters 4 and 5, indicates simultaneous construction, while the same could be concluded for pilasters 1, 2, 3 and 8. Most of wall 4 and the space between the pilasters of wall 2 were built using clay, most likely simultaneously. The only segment that completely stands out regarding its construction technique is the second segment of wall 1 . In this case, part of the wall is built of a completely different material, using a completely different construction technique and the most accessible and cheapest binding material - clay. It can be concluded that this segment of the wall is an obvious modification from a later period. Although built using more modest materials, it is noticeable that the fragments of tegulae, imbrices and bricks are carefully and neatly arranged.

The walls of the building were not founded in sterile soil, but in a layer that served as the filling of the defensive ditch. The lack of more massive foundations was partially compensated by the high construction quality of individual walls and columns. The foundation zones of the walls were of different quality and height, from 0.30 to $0.70 \mathrm{~m}$. Wall 1 was built above the east side of the defensive ditch, and it can be said to have been erected on the most stable terrain. The lowest point of its foundation zone is only 0.05-0.20 $\mathrm{m}$ above the sterile soil. Other walls and columns were erected on a much more unstable part of the ditch filling. An interesting solution was noted 
on the example of wall 3, where the statics of the structure were supported by the use of the spolia - a larger block of limestone, with one of its parts placed under pilaster 5 , and the other one under the eastern part of the wall. In this way, a certain constructive connection between the two separated wall segments was achieved, while the foundation itself was strengthened.

Wall 1 was partially buried, which can be seen from the height to which the outside face of the wall was plastered. In addition to this, it is noted that the larger pieces of schist face the inner side of the building on wall 2, whereas on the outside they were arranged without a particular order. It is noticeable that pilasters 1, 2 and 3 were properly and (mostly) evenly plastered on the inside, while on their outer side there are no visible traces of flattening of the applied lime mortar. The partially preserved wall 4 has pieces of schist facing the inner side with their flat part, while the mortar on the outside of pilaster 8 is not polished, the same being true for pilasters 1,2 and 3 . It can be concluded that walls 2 and 4 were buried at least up to the level of the preserved height, while wall 1 was buried only up to the level which had no traces of plastering. As far as the building level is concerned, it should be emphasized that the level of the floor inside the building is about $2 \mathrm{~m}$ below the level of the main street used in late antiquity.

Although window openings were not noticed, it can be assumed that windows were placed on wall 3. It was the wall of the highest quality, and it most likely provided the greatest amount of light. In addition, if we accept the possibility that walls 2 and 4 were mostly buried, and that wall 1 was facing a neighboring building to the east in its immediate vicinity, the only remaining wall which could have had windows is wall 3 . The current state of exploration of the area south of building 7 allows the conclusion that no building was located on that side. The presence of fragments of window glass (cat. No. 19) in the southern half of the building supports the assumption that the windows were located on wall 3.

\section{SMALL FINDS}

A large number of small finds were discovered in the layers inside the building. ${ }^{4}$ The most numerous finds from the horizon of use of this building are certainly animal bones and fragments of ceramic vessels. Among other finds, metal objects are dominant, the most numerous of which are coins. In addition to 20 specimens of coins, 23 other small finds were discovered in the building (Fig. 10-11).

Discovered specimens of bronze coins date from the beginning to the seventh decade of the fourth century. Below the floor level, most specimens are dated to the fourth century, and the coins from the period 335/341 AD are dated the most accurately. The coins above the floor level point to the fact that the building was in use in the middle of the fourth century, because the latest date is the year 361. This could indicate the time of construction of the building during the fourth or fifth decade of the fourth century, and shows that it was used for only a couple of decades, after which it was abandoned.

Four finds of iron weaponry were discovered in the building - one arrowhead and three spearbutts. The arrowhead (cat. No. 1) has a flat, leafshaped head with a tang. The arrowheads with a flat head of triangular, deltoid and rhomboid shape and tang instead of a socket, were found in the late Roman and early Byzantine horizons of the sites in the Iron Gates area (Špehar 2010: 130). The spear-butts (cat. Nos. 2-4) are conical in shape, in the form of a socket with a pointed tip, and have remains of wood in the interior. The spear-butts are one of the basic elements of the Roman spear - the iron reinforcement of the back end of the spear. This pointed tip served for sticking the spear into the ground, but also as a secondary weapon in case of emergency or damage to the spearhead (Bishop and Coulston 2006:

4 Only small finds located inside the building, in its lower layers i.e. from the horizon of its use, were taken into account, while the finds from the layer accumulated after the cessation of the building's use, were not included in the paper. 

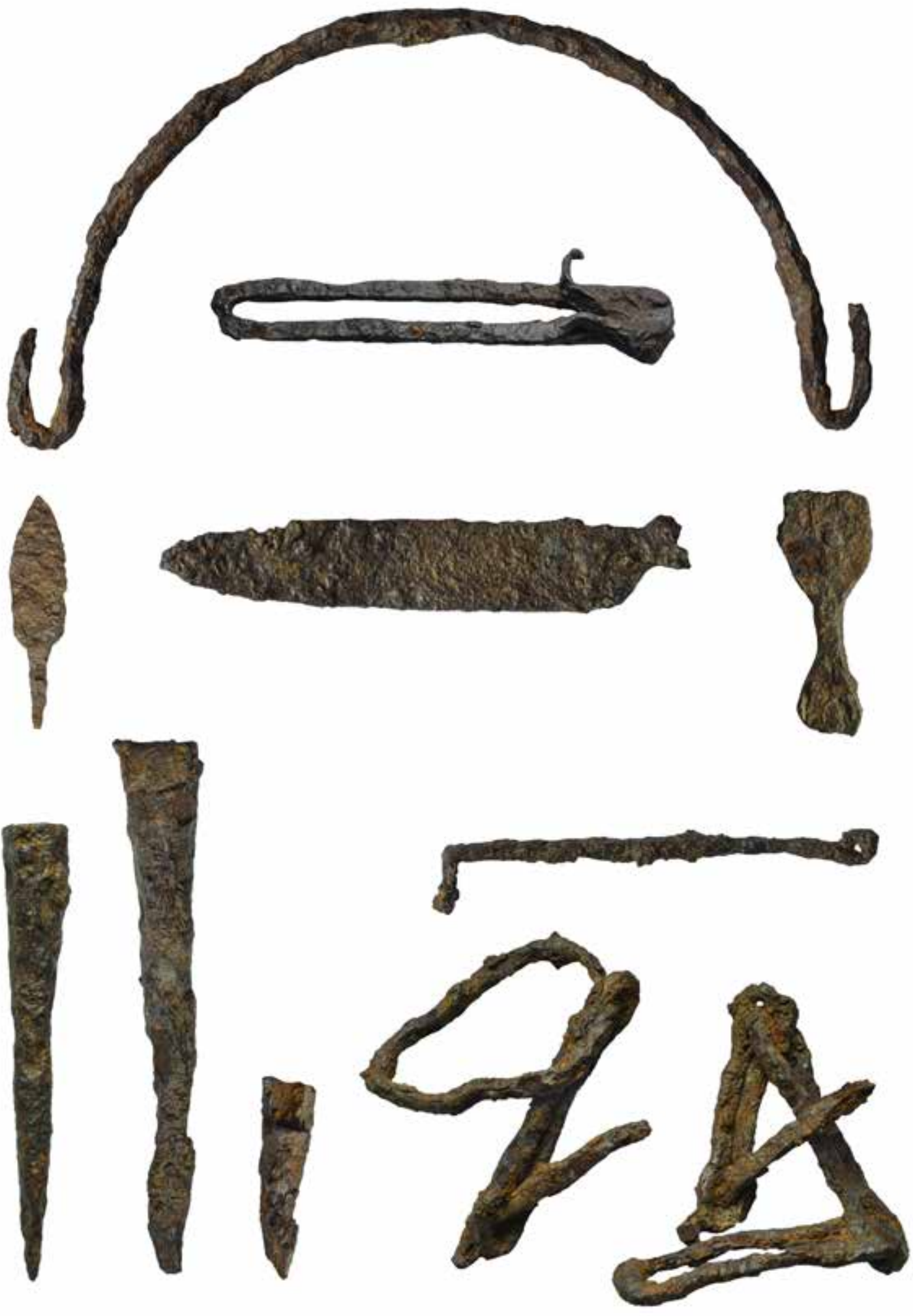

Fig. 10 Small finds 


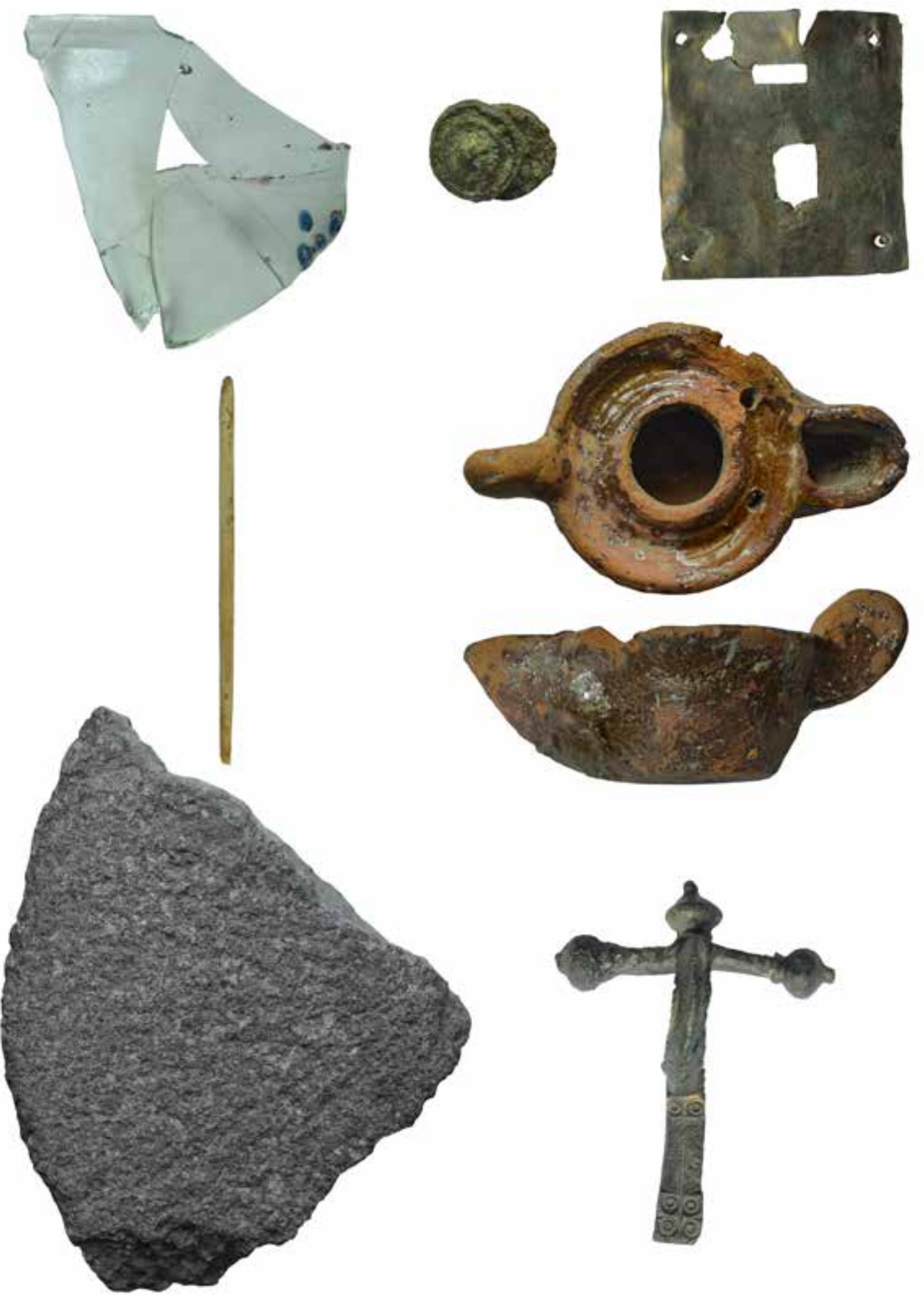

Fig. 11 Small finds 
53). The finds of the weapons can be explained by the presence of an army (especially veterans) in the immediate vicinity of the facility. It should be emphasized that due to great social changes in late antiquity, the army and economic-agricultural activities were not strictly separated.

Other items mainly point to household activities, and these are primarily items for everyday use. An iron chain, a kettle / bucket handle, an iron knife, a fragment of a millstone, and several iron tools could be interpreted as household items. Two segments of an iron chain (cat. No. 5), composed of elongated links of rectangular cross-section, have been preserved. Chains had multiple purposes in antiquity, and they were mostly used for economic activities - for tying up animals, for hanging vessels above the hearth, as parts of a plow, etc. According to its dimensions, it can be assumed that our example could have been used for hanging a kettle over the fire (Петровић 1996: 22). The iron handle with folded ends (cat. No. 6) could have belonged to a smaller iron cauldron, or a wooden bucket for drawing water, etc. Similar specimens were discovered in the late Roman horizons of the sites in the Iron Gates area (Špehar 2010: 115). The single-edged knife (cat. No. 7) belongs to objects with a variety of uses and could have been used both in the kitchen and in a number of other activities. The fragment of the millstone (cat. No. 17) was probably the upper part of a hand mill - catillus. This type of millstone - a conical millstone with parallel upper and lower sides, is broadly dated to the period from the second to the fourth/fifth century (Jovićić 2019: 193, type IV). Although it could have been used for its main function - grinding grains, it is not excluded that this item was used as a building material in secondary use. Fragments of millstones were often used as spolia, for the construction of parts of the walls, which is also the case in other buildings of late Roman architecture of Viminacium (Nikolić, Stojić i Marjanović, 2018a: 62-63, 67). Three iron tools of unknown purpose were discovered in the building, two of which were probably parts of a larger object (cat. No. 8-10). A massive nail with a pyramidal head (cat. No. 11) was singled out. It was probably used in construction, as well as a circular massive iron object (cat. No. 12), which has not yet been precisely identified. These finds may indicate potential economic activities in the building.

Three bronze objects were also discovered - a button, a lock escutcheon and a crossbow fibula. The double button (cat. No. 13) consists of a flat head and a foot, which were decorated with concentric circles; these two segments are connected by a short axis. Buttons appear in similar forms throughout the Empire, and can have both a decorative and a utilitarian function. These items have a wide application in buttoning clothes, belt sets, or parts of a horse harness (Redžić 2013: 303, 311). Based on the shorter length of the axis, it can be assumed that our specimen was most likely used for buttoning clothes. The rectangular lock escutcheon (cat. No. 14) has two smaller rectangular keyholes and four perforations for fastening to the base. The lock escutcheons were applied to the outer side of the lock and were placed on a wooden base. Depending on the dimensions, they could have been used for locking small caskets or boxes, cabinets, chests or doors (Busuladžić 2018: 134). The specimen of the fibula (cat. No. 15) belongs to the type of crossbow fibulae, which originated from similar, T fibula with a hinge. Crossbow fibulae appeared at the end of the third century and were in use during the fourth and the fifth centuries, and recorded on the territory of the entire Empire. The decorations that appear on the arch and the foot are various, and the motif of circles on the foot, noticed also on our specimen, is quite prevalent. Most of the fibulae of this type discovered at Viminacium are dated to the fourth century (Redžić 2007: 65-66). The ceramic oil lamp with olive-green glaze (cat. No. 16) belongs to the group of late Roman glazed lamps, a type of cup-shaped lamp. They appear in several similar variants, and their main feature is a much wider opening for oil on the disc and nozzle and a surface with glaze of different shades of yellow, brown and green. This type of lamp appears in the third century, and there are specimens dating to the 
middle of the fifth century, and even to the early Byzantine period (Korać 2018: 381, Крунић 2011: 300). The largest number of specimens of this type of lamp from Viminacium is dated to the fourth century (Korać 2018: 381-382). Several fragments of window glass (cat. No. 19) with flattened edges were found in the southern part of the building, which may indicate the position of the window on wall 3. Fragments of three glass vessels, belonging to characteristic late antique types, were also discovered. A fragment of a cup (cat. No. 20) with an elongated hemispherical recipient and a slightly indented rim with a straight edge has an ornament in the form of dark blue drops grouped in a cluster. This type of cup can be dated to late antiquity, mostly to the period of the fourth century, both in form and decoration (Ružić 1994: 46). A fragment of the outward folded rim made of transparent olive-green glass (cat. No. 21) probably belonged to some form of a jar with a spherical recipient. Jars of this type had an outward folded rim, spherical recipient, and a flat or annular base. They were ordinary household items, but they were also sometimes used as urns. This form appears from the second century, and was in use until the end of the fourth century (Isings 1957: 111, form 94). A shallow bowl with a flat rim (cat. No. 22) is made of dark blue opaque glass, and on the inside the remains of a white glass threads ornament are visible. Unfortunately, only a small fragment of the rim and the recipient has been preserved, so neither the shape nor the decoration of this vessel can be determined more precisely. The only find made of bone is a hairpin (cat. No. 23) with a rounded, unaccentuated head and a damaged tip. This type of hairpin is not chronologically indicative, and there is a possibility that it is a larger pin with a damaged head and a worn tip. These finds could be for personal use and everyday life, but they do not indicate any specific activity.

Finally, we should mention a fragment of a marble statue of a woman (cat. No. 18), which is not from the layer of use of the building, but was used as spolia and built into wall $3 .{ }^{5}$ It is the head

5 The fragment of the sculpture was discovered during the of a younger woman made of white marble, probably part of a larger, standing figure. Only a small part of the sculpture has been preserved, outside the original context, so it can only be assumed that it does not belong to the world of late antiquity.

\section{CONCLUDING REMARKS}

Archaeological excavations have shown that a defensive ditch stretched between the military camp and the civilian settlement of Viminacium. The city was surrounded by ramparts as early as the last decades of the second century. Due to increasingly unstable conditions during the middle and second half of the third century, the ditch was closed on the north side with a massive wall (Nikolić, Stojić i Marjanović, 2018: 74-75). In this way, the defense structures of the military camp and the civilian settlement were connected, a larger defended area was obtained, and thus the ditch became redundant. Shortly after the wall was erected, the ditch was filled with earth, and the space along the western rampart was given a completely different purpose. We can assume that due to the danger of barbarian incursions, part of the population sought security within the ramparts. With the increase in the number of inhabitants in the city, there was a need for free space for the construction of new buildings. Seven civilian buildings and five circular kilns were discovered above the investigated part of the defensive ditch. They were most likely economic buildings, although we cannot rule out the possibility that they were also used for housing. They were built of available materials with a noticeable decline in construction techniques compared to the previous period.

Spolia were used in the construction and treated as ordinary construction material, regardless of their aesthetic qualities, which did not affect the place of their installation. The gradual degradation and ruralization of the city is also indicated by the appearance of burials within the city walls. Individ- 
uals buried in 36 graves in the area in front of the western ramparts of the military camp, probably belonged to the Roman population, as indicated by the grave goods and the type of grave construction.

After a detailed analysis, it can be concluded that building 7 is a relatively small, late Roman building, built of high-quality materials and erected in a prominent place, near the military camp and one of the main streets. Some parts of the walls, especially the pilasters, indicate knowledge of the ancient construction technique, so it can be said that they are of exceptional quality, well-founded, and skillfully made. On the other hand, it is surprising that there is no constructive connection between the walls, as is the extremely poor quality of some of their parts. It seems that several masons participated in the construction of the building, and that all available materials were used, including the spolia. It is noteworthy that the building lacks any heating system; there are no remnants of a hypocaust, stoves, or even hearths in it. The use of more luxurious architectural elements was not noticed. There were no decoration techniques (floor tiles, mosaic, wall painting), which we could expect in an urban environment. There were no luxury specimens or imports among the small finds, because they were mainly utilitarian objects, indicating usual everyday or economic activities. Analysis of the small finds supports the assumption that the building was of a public character, although the possibility that it was used for housing a smaller number of people cannot be completely ruled out. Coins and other chronologically indicative finds point to the middle of the fourth century as the time of erection and use of the building.

Based on all the above-stated about building 7, and taking into account the mentioned buildings and kilns in its vicinity, it can be said that it was most likely an economic building, part of a larger craftsmanship complex on one of the main streets of the late Roman Viminacium. For better understanding of the late Roman architecture of Viminacium, as well as the economic conditions in the city in the second half of the fourth and the first decades of the fifth century, additional research of the civilian settlement and its surroundings is necessary.

\section{CATALOGUE}

1. Arrowhead, P1.I/1

Material: Iron

Dimensions: length $8,7 \mathrm{~cm}$, width $2,1 \mathrm{~cm}$

Documentation Center Viminacium, C-3014

Analogies: Ušće Porečke reke - Špehar 2010: 130, kat. 711, T. XXXIX/711

- Iron arrowhead consisting of a flat leaf-shaped blade and a tang of rectangular cross-section.

\section{Spear-butt, Pl.I/3}

Material: Iron

Dimensions: length $12,6 \mathrm{~cm}$, width $1,8 \mathrm{~cm}$

Documentation Center Viminacium, C-2086

Analogies: numerous analogies throughout the Roman empire-not chronologically determinable -Conical iron spear-butt in the shape of a pointed socket, with a small slot on the joint. Remnants of wood are visible inside.

3. Spear-butt, P1.I/4

Material: Iron

Dimensions: length $14 \mathrm{~cm}$, width $2 \mathrm{~cm}$

Documentation Center Viminacium, C-2116

Analogies: numerous analogies throughout the Roman empire-not chronologically determinable - Conical iron spear-butt in the shape of a pointed socket, with remnants of wood inside.

4. Spear-butt, P1.I/2

Material: Iron

Dimensions: 5,6 x $1,5 \mathrm{~cm}$

Documentation Center Viminacium, C-2992

Analogies: numerous analogies throughout the Roman empire-not chronologically determinable

- Conical iron spear-butt in the shape of a pointed socket, with remnants of wood inside. 
5. Chain, P1.I/5

Material: Iron

Dimensions: hoop length 7-9 cm, hoop width 5-6 $\mathrm{mm}$

Documentation Center Viminacium, C-2071

Analogies: Surčin - Петровић 1996: 22, кат. 52, сл. $8 / 52$

- Iron chain consisting of seven hoops of rectangular cross-section, which are joined by corrosion.

6. Cauldron handle, Pl.II/1

Material: Iron

Dimensions: length $30,5 \mathrm{~cm}$, stripe width 0,9-1,2 $\mathrm{cm}$

Documentation Center Viminacium, C-2093

Analogies: Sip - Špehar 2010: 115, kat. 569, T. XXXIV/569; Rtkovo-Glamija I - Špehar 2010: 115, kat. 570, T. XXXIV/570

- Cauldron handle made of a curved rod of a rhomboid cross-section. Both ends of the handle are looped.

7. Knife, Pl.I/6

Material: Iron

Dimensions: length $12,2 \mathrm{~cm}$, width $2 \mathrm{~cm}$ Documentation Center Viminacium, C-2088

Analogies: numerous analogies throughout the Roman empire-not chronologically determinable -A single-edged iron knife with a part of a tang remaining. The blade is straight, with a slightly curved cutting edge and flat dorsal side. The lower part of the blade turns into a tang (broken) for planting a handle.

\section{Tool, Pl.I/7}

Material: Iron

Dimensions: length $7,2 \mathrm{~cm}$, width $2,8 \mathrm{~cm}$

Documentation Center Viminacium, C-2097

Analogies: /

-Twofold iron tool of unknown use, consisting of two fan-shaped pieces of uneven size.
9. Tool, Pl.II/2

Material: Iron

Dimensions: length $12 \mathrm{~cm}$, width $1,7 \mathrm{~cm}$

Documentation Center Viminacium, C-2134

Analogies: /

Iron tool of unknown use, shaped as an elongated hoop with a damaged extension on one end.

10. Tool, P1.II/3

Material: Iron

Dimensions: length $12,7 \mathrm{~cm}$, diameter $1,9 \mathrm{~cm}$

Documentation Center Viminacium, C-2979

Analogies: /

Iron tool of unknown use, consisting of an axis with two circular parts at both ends.

11. Nail, Pl.II/4

Material: Iron

Dimensions: length $21 \mathrm{~cm}$

Documentation Center Viminacium, C-3011

Analogies: numerous analogies throughout the Roman empire-not chronologically determinable - Iron nail with a pyramidal head.

12. Object, P1.II/5

Material: Iron

Dimensions: diameter $6 \mathrm{~cm}$, thickness 4-7 mm

Documentation Center Viminacium, C-3012

Analogies: /

- Circular iron object of unknown use.

13. Button, P1.III/3

Material: Bronze

Dimensions: diameter 2,3 cm, width $1,1 \mathrm{~cm}$

Documentation Center Viminacium, C-2101

Analogies: Viminacium - Redžić 2013: 311, 312,

Tip XXIV, Varijanta 2, kat. 777-779 (od poslednje trećine II do druge trećine III veka); Žujince-Crkvište - Redžić 2013: 311, Tip XXIV, Varijanta 2, kat. 776 (od poslednje trećine II do druge trećine III veka)

-Bronze button consisting of a flat circular head, flat circular foot, and an axis between them. The head and the foot are decorated with concentric circles. 
14. Lock escutcheon, Pl.III/1

Material: Bronze

Dimensions: $6,9 \times 6,2 \mathrm{~cm}$

Documentation Center Viminacium, C-3013

Analogies: Singidunum-castrum - Крунић, 1997: 221, кат. 354 (III век); Lepenica - Kiseljak Busuladžić, 2018: 143, cat. No. 201, Plate 19/8 -Square escutcheon of a lock, made of a thin bronze sheet. There are four small perforations in corners for affixing to the wooden door, and two rectangular apertures in the center.

15. Fibula, Pl.III/2

Material: Bronze

Dimensions: length $6,4 \mathrm{~cm}$, width $4,9 \mathrm{~cm}$

Documentation Center Viminacium, C-3017

Analogies: Felix Romuliana - Petković, 2010: 127, cat. No. 10 (the beginning of the IV century); Viminacium - Redžić, 2007: 65,66, 68, TIP XXXVI, Varijanta 3, kat. 387-389 (IV vek)

-Bronze crossbow fibula with an arched semi-circular bow of a triangular cross-section, and a rectangular flat foot. The head of the fibula has a wide transverse bar with three onion-shaped bulbs. The foot is decorated with concentric circles.

16. Lamp, Pl.III/4

Material: Ceramic

Dimensions: 9,7 x $6 \mathrm{~cm}$; length 9,7 cm, disc diameter $6 \mathrm{~cm}$, base diameter $3,3 \mathrm{~cm}$.

Documentation Center Viminacium, C-2090

Analogies: Viminacium - Korać 2018: 381-382; type Viminacium XXII, Variant 1 (late III and IV century); Singidunum- Крунић 2011: 300, тип XXIX -Lamp with a circular discus with a slightly accentuated rim, oval nozzle additionally modeled by hand, a flat base and a vertical handle. The edge of the filling hole is vertically modeled. Two opposed air holes are placed on the discus. The lamp is reddish fired with traces of an olive green glaze.

17. Millstone, Fig.11

Material: Quartzite

Dimensions: $21 \times 16 \mathrm{~cm}$, thickness 5,2 cm, diam- eter $31 \mathrm{~cm}$

Documentation Center Viminacium, C-2095 Analogies: Sirmium - Jovičić 2019: 193, Tip IV, kat. 99, T.VII/99 (prva polovina IV veka); Felix Romuliana - Jovičić 2019: 193, Tip IV, kat. 101, T.VIII/101 (kasnoantički i ranovizantijski period) - Fragment of a conical catillus - upper part of a hand mill, made of a greyish quartzite. The central aperture is only partially preserved. The upper side is flat, rising straight from the edge towards the aperture, while the lower side is concave and parallel with the upper one.

18. Sculpture - head of a woman, Pl.III/6

Material: Marble

Dimensions: $17 \times 17 \times 16 \mathrm{~cm}$

Documentation Center Viminacium, C-4151

Analogies: /

-Fragmented head of a young woman, part of a sculpture made of white marble with light gray veins. The lower part of the face, as well as back of the coiffure, is considerably damaged. The head is shown frontally, with slightly accentuated and gentle facial features - almond-shaped eyes, eyebrows, and part of the nose are still visible. The coiffure is modeled with shallow, slightly wavy grooves. On the top of the head, the hair is divided in the middle by a parting, and it is combed towards both sides. Locks curled backwards frame the face, and they are separated from the combed part by a ribbon. The hair on the back of the head is in a bun, which is partially damaged.

\section{Window glass, Pl.IV/1}

Material: Glass

Dimensions: $8,2 \times 8,4$ (biggest fragment), thickness 1-3 mm

Documentation Center Viminacium, C- 3015

Analogies:/

Several fragments of flat glass with a rounded edge (possibly window glass), transparent, of light blue color. 
20. Cup, Pl.IV/2

Material: Glass

Dimensions: rim diameter $11 \mathrm{~cm}$

Documentation Center Viminacium, C-2986

Analogies: Ad Miliaria (Batina) - Ružić 1994: 46, tip VII/10b, kat. 779, T.XXXIII/5 (IV vek)

Fragmented cup with a flat-edged, slightly indented rim and an elongated, hemispherical recipient. It is made of transparent olive green glass, with a decoration of several small navy blue drops grouped in a cluster.

21. Jar, P1.IV/4

Material: Glass

Dimensions: rim diameter $12,5 \mathrm{~cm}$

Documentation Center Viminacium, C-3023, C-2983

Analogies: Isings 1957: 111, form 94 (2nd to 4th century)

Two fragments of a glass vessel, possibly a jar, made of transparent olive green glass. Remaining part is wide funneled rim with rounded edge, folded outward.

22. Bowl, Pl.IV/3

Material: Glass

Dimensions: rim diameter $22 \mathrm{~cm}$ (?)

Documentation Center Viminacium, C-3016

Analogies: /

A shallow bowl with flat rim. It is made of opaque dark navy glass, with remnants of a white decoration on the inner side.

23. Pin/hairpin, Pl.III/5

Material: Bone

Dimensions: length $9,5 \mathrm{~cm}$

Documentation Center Viminacium, C-2096

Analogies: /

Bone pin with a slightly rounded head and a damaged tip.

\section{BIBLIOGRAPHY}

Bishop, M. and Coulston, J. 2006

Roman military equipment. From the Punic wars to the fall of Rome. Oxford: Oxbow Books

\section{Busuladžić, A. 2018}

Metalwork from Roman doors - examples in Bosnia and Herzegovina. Godišnjak ANUBiH, 47: 117-175.

\section{Isings, C. 1957}

Roman Glass from Dated Finds. Archaeologica Traiectina 2: Groningen: J. B. Wolters

\section{Jovičić, M. 2019.}

Antički žrvnjevi iz rimskih provincija na tlu Srbije. Doktorska disertacija: Univerzitet u Beogradu, Filozofski fakultet, Odeljenje za arheologiju.

\section{Korać, M., Golubović, S., Mrđić, N. 2018}

Research of Viminacium and its Suburban Zones, in: Vivere Militare Est - From Populus to Emperors - Living on the Frontier Vol. II, Monographies, No. 68/2: Belgrade: Institute of Archaeology, 41-71.

\section{Korać, M. 2018}

Oil-lamps from Viminacium (Upper Moesia). Belgrade: Institute of Archaeology.

\section{Крунић, С. 1997}

Употребни предмети, у: Крунић, С. (ур.) Античка бронза Сингидунума. Београд: Музеј града Београда, 188-229.

(Krunić, S. 1997

Upotrebni predmeti, u: Krunić, S. (ur.) Antička bronza Singidunuma. Beograd: Muzej grada Beograda, 188-229).

\section{Крунић, С. 2011}

Античке светиљке из Музеја града Београда. Београд: Музеј града Београда (Krunić, S. 2011 Antičke svetiljke iz Muzeja grada Beograda, Beograd: Muzej grada Beograda). 
Mirković, M. 1968.

Rimski gradovi na Dunavu u Gornjoj Meziji. Beograd: Arheološko društvo Jugoslavije.

Mirković, M. 1986.

Inscriptions de la Mésie Supérieure II. Viminacium et Margum. Beograd: Centre d’Études Épigraphiques et Numismatiques.

\section{Nikolić, E. 2013}

Contribution to the Study of Roman Architecture in Viminacium: Construction Materials and Building Techniques, Archaeology and Science 8: 19-46.

\section{Nikolić, S., Stojić, G., Marjanović, M. 2018}

Istraživanja na lokalitetu Čair-castrum (Viminacijum) 2016. godine, u: I. Bugarski, N. Gavrilović Vitas, V. Filipović (ur.), Arheologija u Srbiji. Projekti Arheološkog instituta u 2016. godini: Beograd, 68-78.

\section{Nikolić, S., Stojić, G., Marjanović, M. 2018a}

Arheološka istraživanja prostora zapadno od viminacijumskog amfiteatra u 2016. u: I. Bugarski, N. Gavrilović Vitas, V. Filipović (ur.). Arheologija u Srbiji. Projekti Arheološkog instituta u 2016. godini: Beograd, 61-67.

Nikolić et al. - Nikolić, S., Stojić, G., Marjanović, M., Bogdanović, I., Jevtović, Lj. 2019 Istraživanja na lokalitetu Čair - castrum (Viminacijum) 2017. godine, u: I. Bugarski, N. Gavrilović Vitas, V. Filipović (ur.) Arheologija u Srbiji. Projekti Arheološkog instituta u 2017. godini: Beograd 2019, 125-134.

\section{Nikolić, S., Stojić, G., Marjanović, M. 2020}

Legijski logor u Viminacijumu: arheološka istraživanja zapadnog dela bedema u 2018. godini, u: Arheologija u Srbiji. Projekti Arheološkog instituta u 2018. godini. (u štampi)

\section{Petković, S. 2011}

Crossbow Fibulae from Gamzigrad (Romuliana). Starinar LX: 111-136.

\section{Петровић, Б. 1996}

Римски метални налази са локалитета „Калуђерске ливаде“ у Сурчину. Годишњак града Београда, књига XLIII: 13-32.

(Petrović, B. 1996

Rimski metalni nalazi sa lokaliteta „Kaluđerske livade" u Surčinu. Godišnjak grada Beograda XLIII: 13-32).

\section{Redžić, S. 2007}

Nalazi rimskih fibula na nekropolama Viminaciju$m a$. Beograd: Arheološki institut Centar za nove tehnologije.

\section{Redžić, S. 2013}

Rimske pojasne garniture na tlu Srbije od I do IV veka. Doktorska disertacija: Univerzitet u Beogradu, Filozofski fakultet, Odeljenje za arheologiju.

\section{Ružić, M. 1994}

Rimsko staklo u Srbiji, Beograd: Filozofski fakultet.

\section{Špehar, P. 2010}

Materijalna kultura iz ranovizantijskih utvrđenja u Đerdapu, Beograd: Arheološki institut. 


\section{REZIME}

KASNOANTIČKI OBJEKAT NA

LOKALITETU ČAIR-CASTRUM PRILOG PROUČAVANJU PROFANE ARHITEKTURE VIMINACIJUMA

KLJUČNE REČI: KASNA ANTIKA, IV VEK, MEZIJA PRIMA, VIMINACIJUM, KASNOANTIČKA ARHITEKTURA, POKRETNI NALAZI.

Prilikom iskopavanja zone zapadne kapije legijskog logora na Viminacijumu, 2018. godine je na prostoru odbrambenog rova istražen kasnoantički horizont sa više različitih celina. Tom prilikom otkriven je deo manje nekropole, sedam građevina i pet kružnih peći. Ove celine su podignute pretežno na prostoru odbrambenog rova, nakon njegovog zatrpavanja, a nalaze se severno i južno od komunikacije koja je vodila od zapadne kapije logora ka gradu. Jedna od istraženih građevina je predmet ovog rada, obeležena u dokumentaciji kao objekat 7. Objekat je lociran jugozapadno od kapije i južno od glavne komunikacije koja je vodila od logora ka gradu, na udaljenosti od oko $8 \mathrm{~m} \mathrm{od}$ zapadnog bedema (extra muros). Ima nepravilnu pravougaonu, gotovo kvadratnu osnovu, čije spoljašnje dimenzije iznose 8,10/7,70 x 7,75/6,90 m. Zidovi nisu bili konstruktivno povezani već bočnim stranama naležu jedan na drugog, a njihova najviša očuvana visina iznosi 1,20 m. U izgradnji objekta korišćeni su različiti materijali - fragmenti opeka, tegula i imbreksa, kamena škriljca i blokova od krečnjaka, sporadično i crvenke, a uočena je i upotreba spolija; kao vezivni materijal korišćeni su krečni malter i glina. Na zidovima su uočene prepravke, a u unutrašnjosti i jedan manji pregradni zid, koji predstavlja kasniju dogradnju. Objekat je datovan u IV vek, pre svega na osnovu novca. Pokretni nalazi ukazuju na svakodnevne i ekonomske aktivnosti, izuzev nekoliko primeraka oružja. U širem kontekstu i u odnosu na ostale građevine otkrivene $\mathrm{u}$ istoj zoni, objekat $7 \mathrm{se}$ može protumačiti kao ekonomski objekat koji je bio deo nekog većeg zanatskog kompleksa.
Arheologija i prirodne nauke (Archaeology and Science) is an Open Access Journal. All articles can be downloaded free of charge and used in accordance with the licence Creative Commons - Attribution-NonCommercial-NoDerivs 3.0 Serbia (https://creativecommons.org/licenses/ by-nc-nd/3.0/rs/.

Časopis Arheologija i prirodne nauke je dostupan u režimu otvorenog pristupa. Članci objavljeni u časopisu mogu se besplatno preuzeti sa sajta i koristiti u skladu sa licencom Creative Commons - Autorstvo-Nekomercijalno-Bez prerada 3.0 Srbija (https://creativecommons.org/ licenses/by-nc-nd/3.0/rs/. 

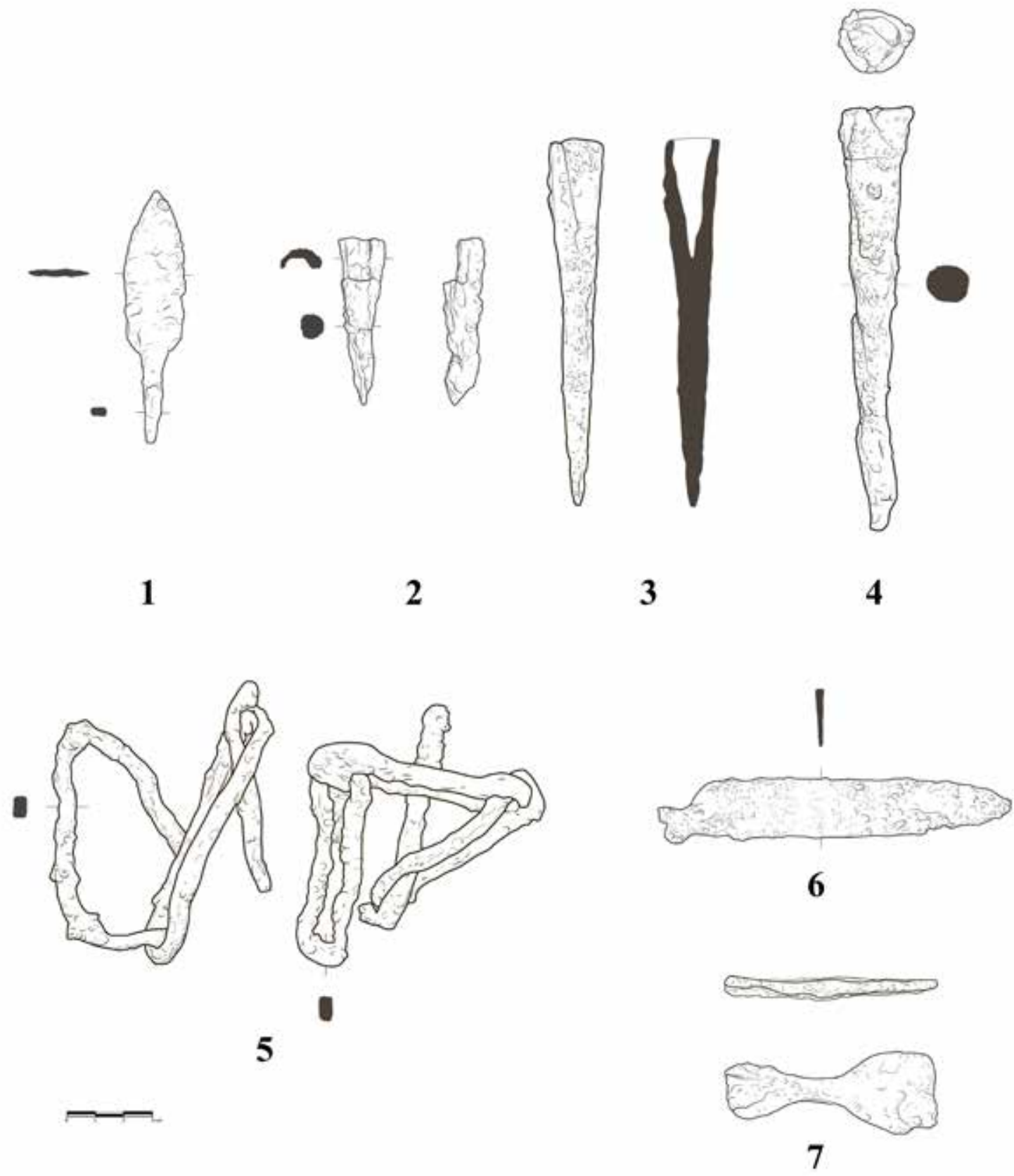

Plate 1 

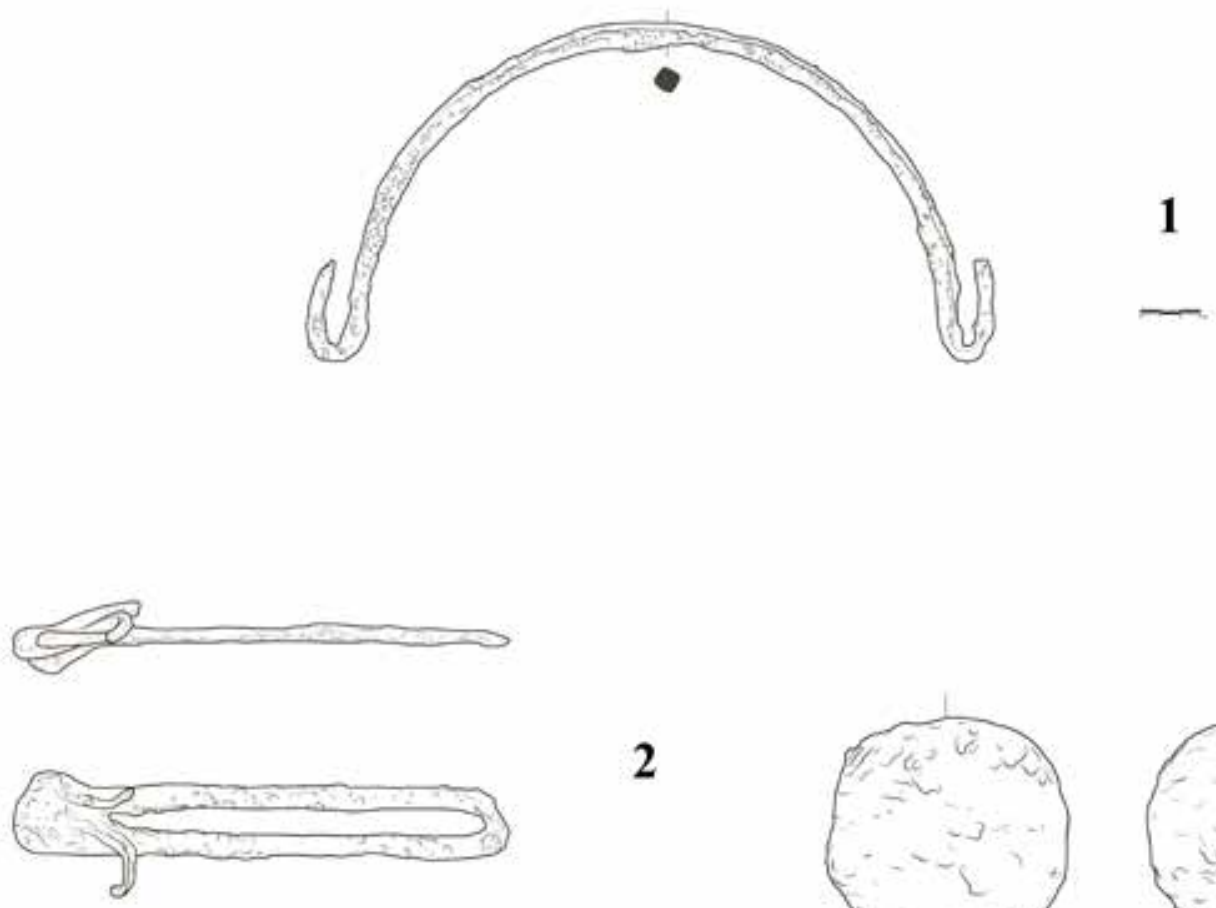

2

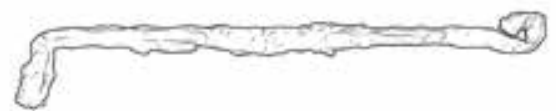

3

(1)
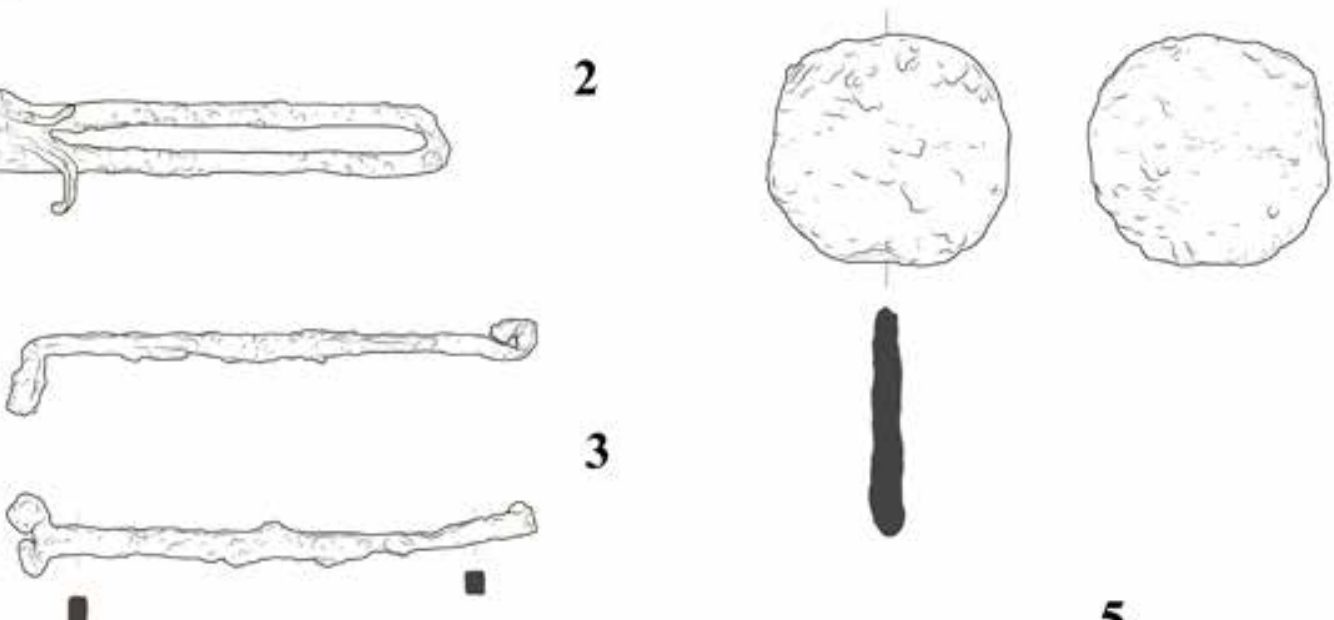

(2)i)

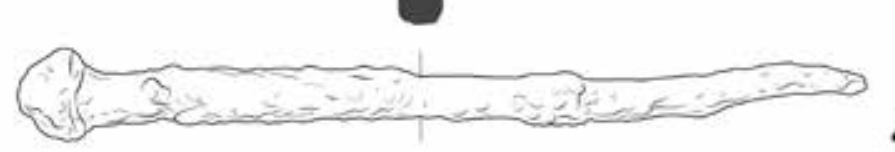

5

4

Plate 2 

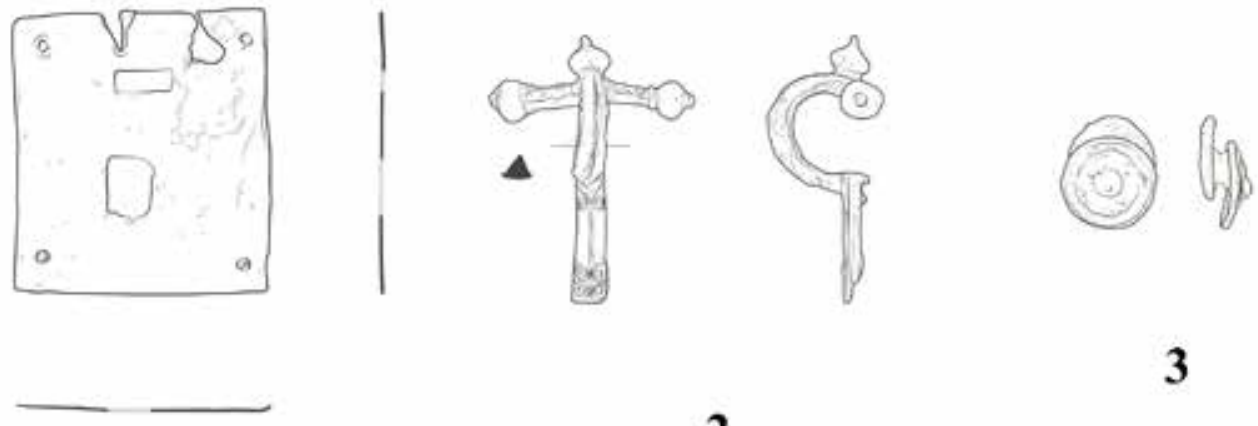

\section{2}

3

\section{1}

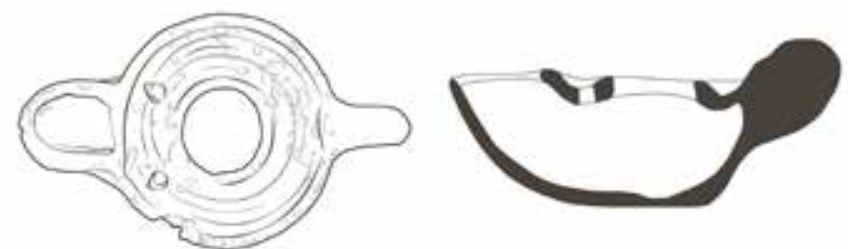

4
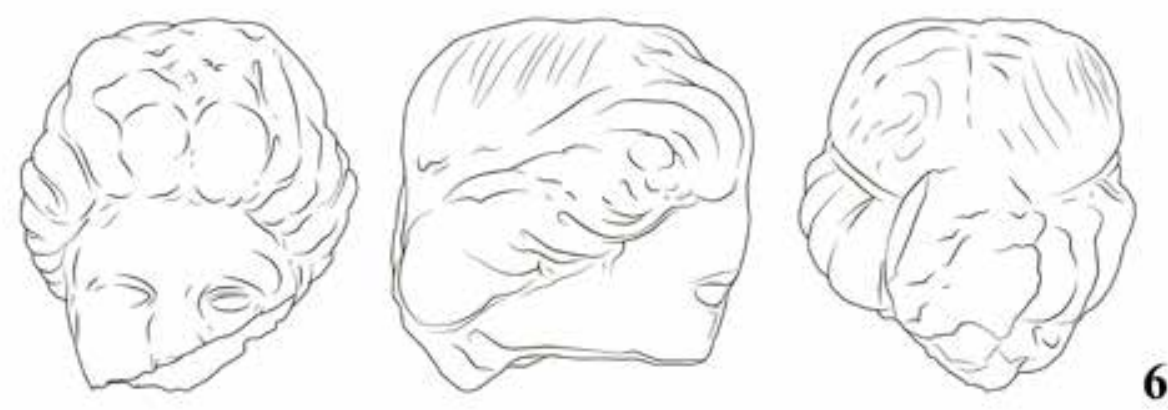

6

Plate 3 

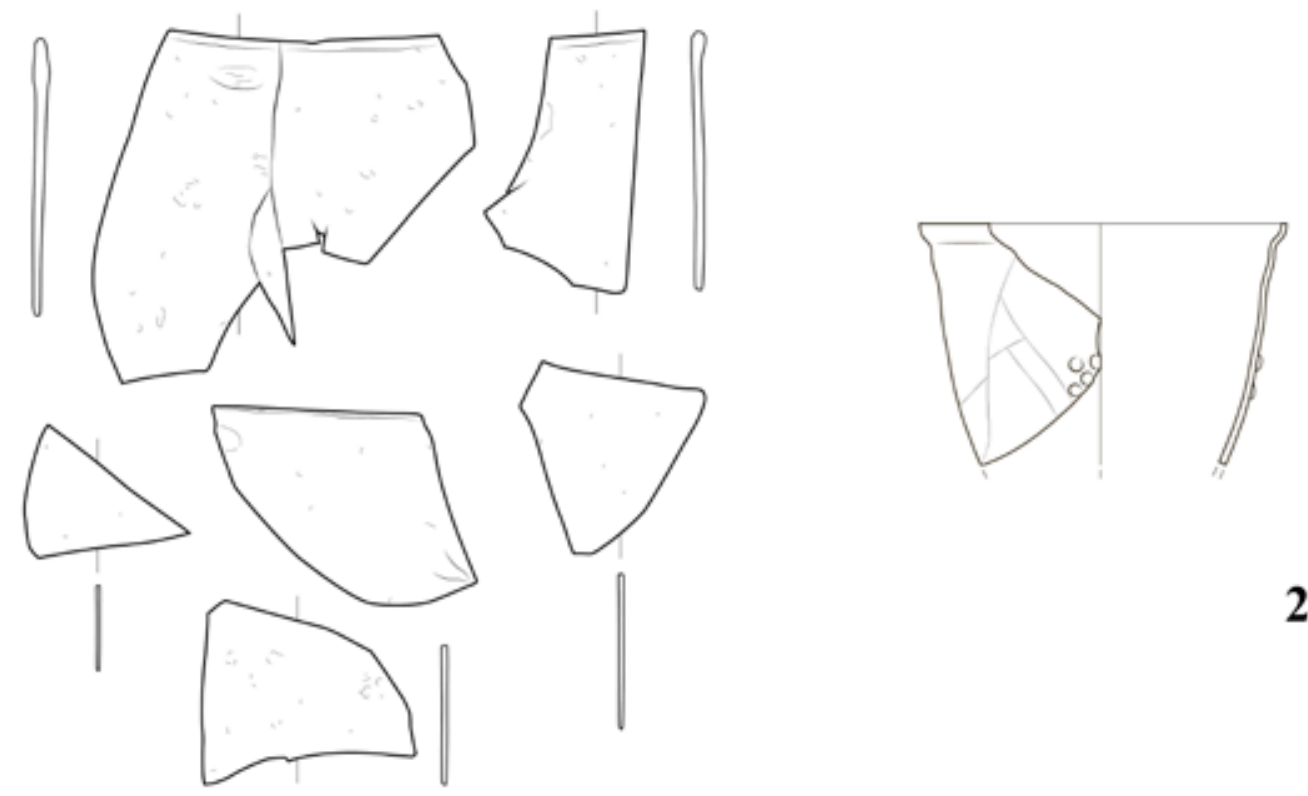

2

1
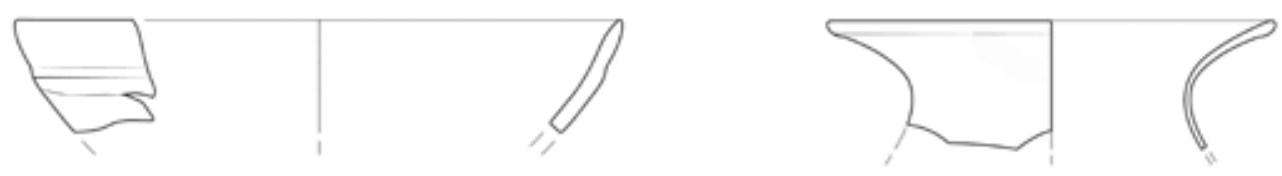

3

Plate 4 